This is a PREPRINT version (pre-refereeing) of the paper: Dyja, V., Hibsch, C., Tarantola, A., Cathelineau M., Boiron M.C., Marignac C, Bartier, D., Carrillo-Rosúa, J., Morales-Ruano, S., Boulvais, P. (2015). From deep to shallow fluid reservoirs: evolution of fluid sources during exhumation of the Sierra Almagrera, Betics, Spain. Geofluids, doi: 10.1111/gfl.12139.

\title{
From deep to shallow fluid reservoirs: evolution of fluid sources during exhumation of the Sierra Almagrera, Betic Cordillera, Spain
}

Vanessa Dyja ${ }^{\mathbf{a}}$, Christian Hibsch ${ }^{\mathbf{a}}$, Alexandre Tarantola ${ }^{\mathbf{a}}$, Michel Cathelineau ${ }^{\mathbf{a}}$, Marie-Christine Boiron $^{\mathbf{a}}$, Christian Marignac ${ }^{\mathbf{a}}$, Danièle Bartier ${ }^{\mathbf{a}}$, Javier Carrillo-Rosúa ${ }^{\mathbf{b}, \mathbf{c}}$, Salvador Morales Ruano b,d , Philippe Boulvais ${ }^{\text {e }}$

${ }^{a}$ GeoRessources, Université de Lorraine, CNRS, CREGU, UMR 7359, Vandœuvre-lès-Nancy, F-54506, France

${ }^{\mathrm{b}}$ Instituto Andaluz de Ciencias de la Tierra (Universidad de Granada-CSIC), Armilla, Granada, Spain

${ }^{\mathrm{c}}$ Dpt. de Didáctica de las Ciencias Experimentales, Facultad de Ciencias de la Educación, Campus de Cartuja, 18071, Granada, Spain

${ }^{\text {d }}$ Dpt. de Mineralogía y Petrología, Facultad de Ciencias, Universidad de Granada, Granada, Spain

${ }^{\mathrm{e}}$ Université de Rennes 1, Géosciences Rennes - UMR CNRS 6118, OSUR, 35042 Rennes Cedex, France

\section{Corresponding Author:}

E-mail Address: vanessa.dyja@univ-lorraine.fr

Postal Address: GeoRessources, UMR 7359, Université de Lorraine, boulevard des Aiguillettes, 54506

Vandœuvre-lès-Nancy

Tel: 0033383684746 Fax: 0033383684701

\section{Keywords}

Fluid inclusions / Betic Cordillera / Metamorphic Core Complex / Trans-alboran fault/ Stable isotopes / Metamorphic brines / evaporites / volcanism

\section{Abstract}

Palaeo-fluids trapped in quartz and siderite-barite veins hosted by graphitic schists recorded the fluid and metal transfers during the Neogene exhumation of the Sierra Almagrera Metamorphic Core Complex. First quartz veins registered the ductile then brittle-ductile extensional shearing. The reservoir at that time was wetted by high-salinity fluids with a low density volatile phase resulting from the dissolved Triassic evaporites. Low salinity fluids occurred during the exhumation within the brittle domain as revealed by transgranular fluid inclusion planes affecting previous veins. This suggests an opening of the system and the penetration of surficial fluids from uplifted ranges during Serravalian to early Tortonian times.

Transcurrent tectonics generated marine basins since late Tortonian. At depth quartz veins discordant to the foliation were associated to hematite indicating oxydizing conditions. A stop of the low-saline record is revealed by high-salinity Fe-rich fluids issued from the underlying metamorphic reservoir. The Messinian ongoing activity of the sinistral Trans-Alboran tectonovolcanic trend led to the formation of ore deposits.

Reducing conditions and Fe-rich fluid led to the formation of siderite and pyrite. The subsequent formation of galena and barite under oxydizing conditions has been related to a probable increase of temperature. A higher salinity and the $\mathrm{Cl} / \mathrm{Br}$ ratio indicate another source of secondary brine issued from dissolved Messinian evaporites as confirmed by $\delta^{34} \mathrm{~S}$ signature of barite.

Transcurrent tectonics clearly modified the hydrogeology of the upper reservoir. The faulting connected the deeper and upper reservoir generally separated by the brittle/ductile transition rheological and hydrogeological barrier under extensional tectonic regimes as confirmed by the stage of low-saline fluids. 


\section{Introduction}

Fluids, vectors of heat and elements, play major roles in many geologic processes of the Earth's crust. Migration of fluids is linked to local and regional geology, where permeability is a key factor in fluid flow (Manning \& Ingebritsen, 1999, Ingebritsen \& Manning, 2002). Permeability is a function of time, heterogeneity - anisotropy, and scale (Manning \& Ingebritsen, 1999). The Sierra Almagrera is a favourable place to evaluate the migration of fluids within the Earth's crust. Because the area is located in a context of exhumation disturbed by the trans-alboran transcurrent fault system, fluid flows can be studied through time at different scale, and according to different rock mechanic behaviours.

Exhumation of metamorphic core complexes within Basin and Range provinces is usually favoured by extensional tectonics revealed by the presence of crustal detachments associated to low-angle and high-angle normal faults (Wernicke \& Burchfiel, 1982, Lister \& Davis, 1989, Vanderhaeghe \& Teyssier, 2001). During this evolution, the location of the brittle-ductile transition plays a major role. This rheological transition may localise detachment and decollement layers where normal faults are generally rooted and plays also a major hydrogeological role. It separates a deep reservoir that can be accessible to metamorphic and/or magmatic and mantle fluids confined under lithostatic conditions, and a shallower reservoir accessible to surficial fluids (meteoric, marine or basinal) circulating under lithostatic to hydrostatic conditions (Morrison \& Anderson, 1998, Famin \& Nakashima, 2004). These two reservoirs may interact through tectonic and magmatic processes. Under extensional regimes, surficial fluids may reach the upper part of deeper reservoir (Mulch et al., 2004, Famin et al., 2005, Siebenaller et al., 2013), or, conversely, deeper fluids may access to the upper brittle crust and mix with more surficial fluids (Boiron et al., 2003), a process which may also be triggered by magma ascent. Such fluid circulation events are commonly associated to hydrothermal processes (metasomatism, mineralisation) (Beaudoin, 1994), and it is then necessary to decipher the role played by the different reservoirs and fluids through the tectonic and magmatic events.

In the Betic range (SE Spain), subduction-related high-pressure low-temperature metamorphism was followed by collision (Cretaceous-Oligocene) and extensional tectonics due gravitational inestability. This extension generated metamorphic core complexes in the internal zones at the first stage of exhumation during Miocene (between 18 to $14 \mathrm{Ma}$ : Gomez-Pugnaire et al. (2004), Platt et al. (2006) and Gomez-Pugnaire (2012)) or late Oligocene to early Miocene (30 Ma high-pressure to 22-18 Ma high-temperature low-pressure (Augier et al., 2005b). Further exhumation was related to the late Miocene major transcurrent fault system, which led to the formation of synsedimentary continental to marine basins (Weijermars, 1985, Booth-Rea et al., 2003). A mafic to felsic volcanism occurred reflecting mantle, and crust processes and mantle-crust interactions at depth (e.g. Benito et al. (1999); Turner et al. (1999); Duggen et al. (2004)). Erosion affected the uplifted structures and contributed to the exhumation within the sierras but a major erosional event affected both basins and ranges during the Messinian salinity crisis. This is revealed by the deposition of evaporites in the central Mediterranean Sea and incision features affecting the bordering slopes. Prior to the main sea-level drop, a first stage of deposition of evaporites has been recorded in some basins from the Betics (Clauzon, 1980, Gautier et al., 1994, Krijgsman et al., 2000, Gargani et al., 2008, Omodeo Salé et al., 2012).

The Sierra Almagrera metamorphic core complex exhibits a sequence of quartz veins that we interpret as a record of the ductile to brittle transition. A series of siderite and barite base metalbearing ore veins, and quartz and carbonate barren veins in the brittle domain associated with the transcurrent tectonics. Fluid inclusion study of the different fluids trapped in this vein sequence allows the characterisation of the deep reservoir fluids in equilibrium with the rocks during the ductile stage and the evolution of the fluids within the same reservoir during its exhumation towards its present exposure. Acting as a kind of probe, this reservoir experienced different types of deformation styles, from ductile to brittle, and record the Neogene paleotopographic, thermal and paleohydrogeological evolution of this part of the Betic orogenic wedge. 


\section{Geological context}

\subsection{The Betic Cordillera (SE Spain)}

The Betic Cordillera results from the convergence between Africa and Eurasia plates since Eocene, and forms an alpine tectonic wedge that reaches a thickness of about $60 \mathrm{~km}$ (Platt \& Vissers, 1989, Lonergan \& White, 1997, Platt, 2007, Jolivet et al., 2008). The internal Alboran domain could be divided into three main tectono-metamorphic nappes, from bottom to top (Figure 1) : (i) the Nevado-Filábride itself divided into three sub-units from bottom to top: Ragua (not represented on Fig. 1, to the W), Calar-Alto and Bedar-Macael (De Jong, 1991, Martínez-Martínez et al., 2002), (ii) the Alpujarride, and (iii) the Malaguide nappes (Egeler \& Simon, 1969b). In addition to isostatic uplift, these units were also exhumed due to tectonic unroofing (Lonergan \& Mange-Rajetzky, 1994). The associated WSW-ENE striking tectonic extension related to the exhumation of the metamorphic continental crust is supposed to have resulted from partial or complete removal of the lithospheric mantle (Platt \& Vissers, 1989). Other mechanisms such a subduction zone rollback is also argued (Lonergan \& White, 1997, Bezada et al., 2013). Major detachments are joining structural units showing different degrees of metamorphism (Figure 1-a): (1) The Malaguide-Alpujarride contact: unmetamorphosed Malaguide lithologies lie on top of the Alpujarride high-pressure-low temperature metamorphic rocks (Sierra Estancias Figure 1-a), (2) The Filabres major detachment: higher grade Nevado-Filábride metamorphic rocks were exhumed later, during the Miocene, beneath the Alpujarride nappes. Ductile shearing related to this exhumation affects the footwall and shows transport direction top towards WSW to SW (CrespoBlanc et al., 1994, Martínez-Martínez \& Azañón, 2002, Platt, 2007). Following the extensional tectonics expressed in the ductile fabrics, the metamorphic nappes reached the brittle domain during the ongoing exhumation processes. Since late Miocene, both the metamorphic cores and the sedimentary cover have been affected by transcurrent tectonics: the Trans-Alboran system that generated both releasing and restraining areas of deformation creating juxtaposed zones with opposite vertical motions (subsidence and uplifts). These tectonics also contributed to the formation of ranges (sierras) separated by basins either filled by continental or marine sediments according to time and space. This major tectono-volcanic trend can be followed off-shore until the other side of the Mediterranean Sea in Morocco (Hernandez et al., 1987).

The volcanism linked to lithospheric thinning, shows a gradual transition and great diversity in its geochemical affinity. The age of this volcanism varies from $34 \mathrm{Ma}$ (tholeitic dikes in Malaga province) to $2 \mathrm{Ma}$ (alkali basalts in Murcia province). The main magmatic activity in SE Spain and the Alboran Basin took place between 12.6 and $7.5 \mathrm{Ma}$ with tholeitic and calc-alkaline magmatism. The other main episode, with high-K calc-alkaline, shoshonitic and ultrapotassic magmatism occurred inland in SE Spain between 10 and 6.5 Ma (Bellon et al., 1983, Turner et al., 1999, Zeck et al., 2000; Duggen et al., 2004, Duggen et al., 2005, Cesare et al., 2009). Heterogeneous sources and processes are implied in the genesis of this magma : (i) various degrees of partial melting, (ii) metasomatism (i.e. oceanic and continental crust, sediments), (iii) anatexis of crustal metasedimentary basement (Benito et al., 1999, Duggen et al., 2004, Duggen et al., 2005, Prelevic et al., 2008, Álvarez-Valero \& Kriegsman, 2008, Conticelli et al., 2009).

Related to the Neogene evolution of the Betics, a series of base and precious metal-bearing hydrothermal ore systems developed mainly in calc-alkaline volcanic rocks of the Cabo de Gata range, but also in the metamorphic basement and in sedimentary lithologies. Thus, along the sinistral strike-slip fault of the Carboneras segment (part of the Trans-Alboran system), Miocene $\mathrm{Cu}-(\mathrm{Ag}-\mathrm{Au})$ epithermal volcanic hosting mineralisation occurred at Palai-Islica (Morales-Ruano et al. (2000); Carrillo-Rosúa et al. (2009); Figure 1-a). Au and Pb-Zn-Ag-Au ore deposits were not related to this structural system, but occurred within the calc-alkaline vulcanites: at Rodalquilar (Arribas et al., 1995) and San José (Demoustier et al., 1998, Esteban-Arispe et al., 2009). Ba-Ag mineralisations are found in sedimentary rocks, close to high-K calc-alkaline and shoshonitic vulcanites within the Vera Basin (Alvado, 1986, Martínez-Frías, 1998, Carrillo-Rosúa et al., 2002). 


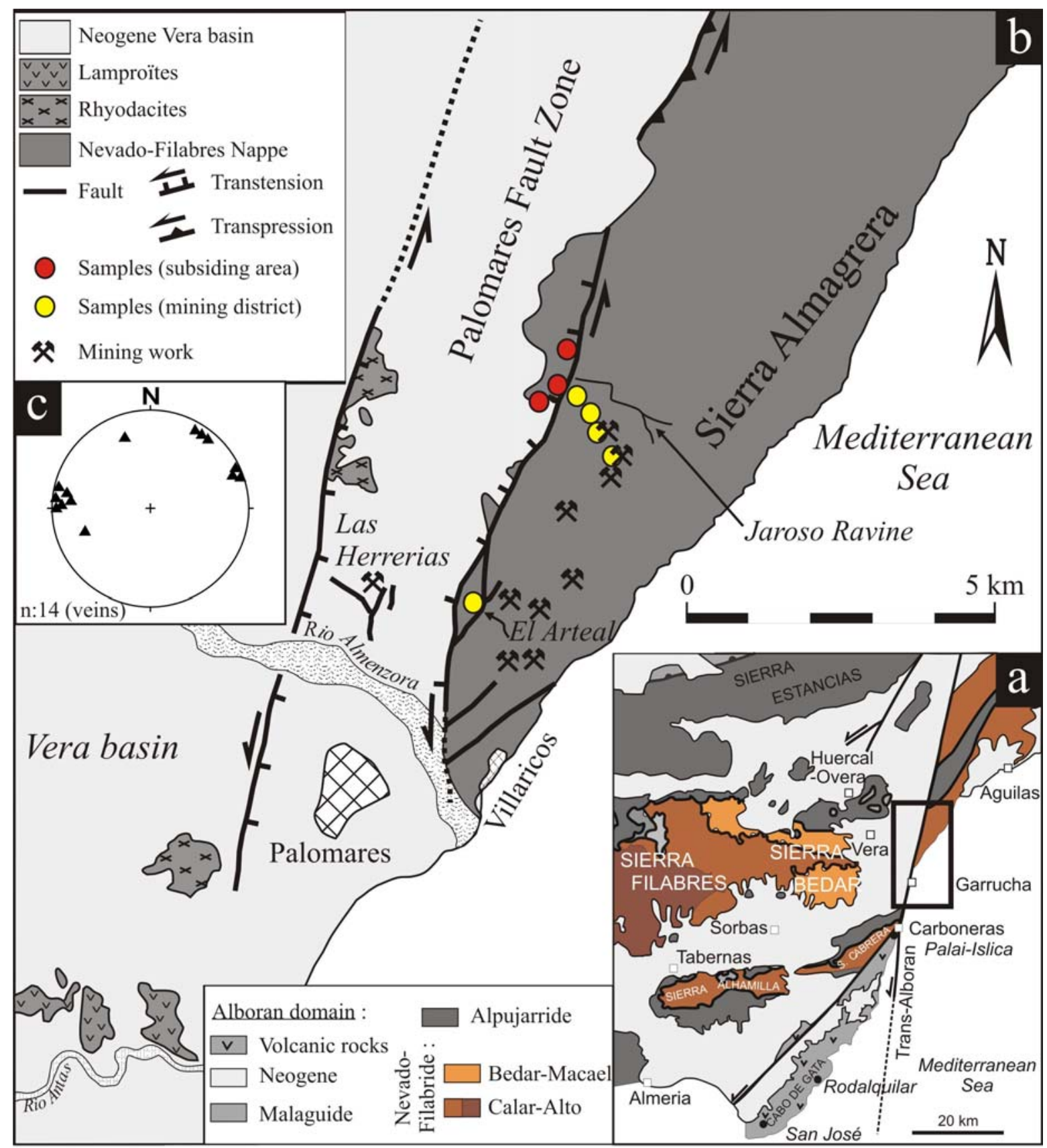

Figure 1 : a) Geological context of the Eastern Betics and location of the Sierra Almagrera (modified after Augier (2004)). b) Geological map of the Sierra Almagrera, Vera basin and Palomares fault zone (modified after Booth-Rea (2004) and Montenat \& Ott D'estevou (1990), and location of sampling areas. c) Poles of mineralized V-ore veins (barite and siderite) in El Arteal tunnel represented on lower hemisphere stereogram.

\subsection{Geology of the Sierra Almagrera (Figure 1-b)}

The metamorphic range of the Sierra Almagrera exposes the Nevado Filabres unit related to the Internal Zone of the Betic Cordillera. The rocks are composed to a large extent of graphitic, quartz-rich chloritoid-schists (Booth-Rea et al., 2004) and quartzites. Locally, carbonates and gypsum are encountered. The present-day geomorphology of the Sierra Almagrera mainly results from the sinistral strike-slip faulting in the area that generated several fault segments at various scales. The Palomares Fault Zone results in an approximately $16 \mathrm{~km}$ North-South trending leftlateral relative displacement (Booth-Rea et al., 2004). This transcurrent faulting may have started during the late Tortonian (around 7.2 Ma) but was mainly active during the Messinian. Its evolution related to a vertical component (oblique faulting) caused the recent exhumation of the Sierra 
Almagrera during the Plio-Quaternary. The southern segments of the Palomares Fault Zone dip towards the West. Their transtensional activity favoured the subsidence of the western block. In contrast, the northern segments which are dipping towards the ESE, are related to a sinistral restraining bend that favoured the uplift of the Sierra Almagrera mountain ranges located to the East of the zone (Booth-Rea et al., 2004). In the studied zone, small bodies of high-K calc-alkaline to shoshonitics rhyodacites (Lopez Ruiz \& Rodriguez Badiola, 1980, Benito et al., 1999) can be encountered along the transcurrent faults. ${ }^{40} \mathrm{Ar} /{ }^{39} \mathrm{Ar}$ ages of these rocks are between 7.4 and $6.4 \mathrm{Ma}$ (Duggen et al., 2004). Less abundant lamproites from the ultrapotassic series (Lopez Ruiz \& Rodriguez Badiola, 1980), dated at 6.4 Ma (Duggen et al., 2004), outcrop within the Vera basin, South of Sierra Almagrera (Figure 1-b).

Ore deposits related to the transcurrent system have been exploited in the area since the Bronze Age (Navarro et al., 1994). Nevertheless, the most active economic period lasted between 1838 and 1934, mainly for $\mathrm{Pb}$ and $\mathrm{Ag}$ (Navarro et al., 1994). Mineralisations in the Sierra Almagrera are found in veins within the metamorphic rocks of the presently uplifted metamorphic range (Figure 1-b). This exploited area will be referred as the "mining district" in this article. Some mineralised veins are still outcropping in the Sierra but the sulfides are frequently oxided. Nonaltered veins can still be sampled along the El Arteal E-W striking horizontal gallery which is only locally collapsed. Subvertical fractures filled by siderite, barite, hematite and ore minerals crosscut the metamorphic fabric of graphitic schists and quartz veins transposed or partly transposed within the main rock foliation. This study shows that the mineralised fractures are organised into two main clusters striking $\mathrm{N} 160^{\circ}-\mathrm{N} 180^{\circ}$, and $\mathrm{N} 120^{\circ}-\mathrm{N} 130^{\circ}$ (Figure 1-c).

The area located within the Palomares Fault Zone (hanging-wall) will be referred as "the subsiding area". Locally, mineralisation can be found within the Messinian sediments (Las Herrerias). The ore consists of barite veins, with native Ag and base-metal sulfides in very small amounts (Alvado, 1986, Martínez-Frías, 1998, Carrillo-Rosúa et al., 2003).

\section{Methods}

\subsection{Fluid inclusion investigations}

\subsubsection{Fluid inclusion petrography}

Double-polished 150-200 $\mu \mathrm{m}$ thick sections were prepared for microscopic and microthermometric observations of mineralised veins of quartz, siderite, barite and calcite. The sections were oriented (azimuth) in order to define present-day strike and dip of fluid inclusion planes. Isolated fluid inclusions or clusters are interpreted as primary. Intragranular fluid inclusion planes are found within single grains in microcracks that do not cross-cut grain boundaries (Van Den Kerkhof \& Hein, 2001). Transgranular fluid inclusion planes result from healing of former open cracks (Krantz, 1983, Boullier, 1999, Lespinasse, 1999, Lespinasse et al., 2005) as rocks undergo brittle deformation. The shape, size and phase of individual inclusion were recorded under a magnification of $\times 1000$ at room temperature with an optical microscope. Systematic measurements of the fluid inclusion planes are carried out on each section using an interactive videographic analyzer ANIMA (Lespinasse et al., 2005). The plunge and dip direction of the FIP are represented in equal lower hemisphere stereograms using Stereonet ${ }^{\circledR}$ software.

\subsubsection{Microthermometry}

Phase transitions of the fluid inclusions can be characterised between $-170{ }^{\circ} \mathrm{C}$ and $+600{ }^{\circ} \mathrm{C}$ using a LINKAM MDS 600 heating-freezing stage mounted on an Olympus microscope, calibrated using $\mathrm{CO}_{2}$ and $\mathrm{H}_{2} \mathrm{O}$ synthetic and natural alpine fluid inclusions. The accuracy of measurements is from $\pm 0.2{ }^{\circ} \mathrm{C}$ at low temperature (experiments at $0.5-1{ }^{\circ} \mathrm{C} / \mathrm{min}$ ) to $\pm 2{ }^{\circ} \mathrm{C}$ at high temperature (experiments at $1-5{ }^{\circ} \mathrm{C} / \mathrm{min}$ ). Abbreviations of terms and temperatures of phase transition 
observations made during microthermometric experiments are reported on Table 1. In barite and calcite, the high temperature transitions were studied first to prevent leakage of fluid inclusions during ice formation on cooling. Photographs of fluid inclusions after each measurement were compared with the original picture to evaluate any leakage.

\begin{tabular}{ll} 
Abbreviation & Observation \\
\hline$-\mathrm{p}$ & Primary fluid inclusion \\
$-\mathrm{ig}$ & Intragranular fluid inclusion plane \\
$-\mathrm{tg}$ & Transgranular fluid inclusion plane \\
$\mathrm{L}$ & Liquid \\
$\mathrm{V}$ & Vapor \\
$\mathrm{S}$ & Solid \\
$\mathrm{flw}$ & Volumetric fraction of the aqueous liquid \\
$T_{\mathrm{e}}$ & Eutectic or apparent eutectic temperature. First formation of visible liquid of the \\
& solid aqueous phase on heating \\
$T_{\mathrm{m}}($ ice $)$ & Final melting temperature of the solid aqueous phase \\
$T_{\mathrm{m}}(\mathrm{cla})$ & Dissociation temperature of clathrate \\
$T_{\mathrm{h}}(\mathrm{L})$ & Bulk homogenization temperature via a bubble-point transition $(\mathrm{L}+\mathrm{V}=\mathrm{L})$ \\
$T_{\mathrm{h}}(\mathrm{V})$ & Bulk homogenization temperature via a dew-point transition $(\mathrm{L}+\mathrm{V}=\mathrm{V})$ \\
\hline
\end{tabular}

Table 1: Abbreviations of terms and temperatures of phase transition observations made during microthermometric experiments.

\subsubsection{Raman microspectroscopy}

Raman analysis of fluid inclusions was performed with a LabRAM microspectrometer (Horiba Jobin Yvon, at GeoRessources, Vandœuvre-lès-Nancy, France) equipped with a 1800 gr.mm $\mathrm{mm}^{-1}$ grating and $\mathrm{a} \times 80$ Olympus objective. The exciting radiation was provided by an $\mathrm{Ar}^{+}$laser (Stabilite 2017, Newport Corp., Spectra Physics) at $514.5 \mathrm{~nm}$ and at a power of $400 \mathrm{~mW}$. Signal-tonoise ratio was optimised adjusting acquisition time and accumulation number. The quantitative analysis of the gas phase was performed using the own calibration of the laboratory. Results are given as $\mathrm{mol} \%$ relative to the gas phase.

\subsubsection{P-V-T-X calculation of fluid inclusions}

Microthermometric data associated with mole fractions of the different gas species obtained by Raman spectroscopy are necessary to reconstruct the $P-V-T-X$ evolution of fluid inclusions. Salinity was calculated using the final melting temperature of ice when the gases are not sufficiently present to form gas hydrates (Bodnar, 2003). In this case, the isochore is a function of the homogenisation temperature for a given salinity and the empirical equation of state of Zhang and Frantz (1987) is used within a $P-T$ domain of validity of $T: 180-700{ }^{\circ} \mathrm{C}$ and $P: 0.1-300 \mathrm{MPa}$.

Salinity and molar volume $\left(V_{\mathrm{m}}\right)$ of the volatile phase were calculated using the program ICE and the dissociation temperature of clathrate (Bakker, 1997, 2003) when the gases are present in significant amount to allow the formation of gas hydrates. The isochores are calculated using the program ISOC (Bakker, 1997, 2003) and the equation of state (Bowers \& Helgeson, 1983) revised by Bakker (1999) for the system $\mathrm{H}_{2} \mathrm{O}-\mathrm{CO}_{2}-\mathrm{CH}_{4}-\mathrm{N}_{2}-\mathrm{NaCl}$, with $P-T$ domain of validity, $T$ : 350-600 ${ }^{\circ} \mathrm{C}$ and $P$ : 50-200 MPa. .

\subsubsection{Crush-leach for halogen chemistry}

Because they display a conservative behaviour in solution, and remain relatively unaffected by fluid-rock interactions (Banks et al., 1991), the halogen $(\mathrm{Cl}$ and $\mathrm{Br}$ ) signature of a fluid can be used to characterise its source (Böhlke \& Irwin, 1992b). 
Bulk crush-leach analyses were performed in extracted fluids hosted in quartz, barite and siderite which were prepared and cleaned according to the methodology of Bottrell et al. (1988). The amount of sample crushed was between 0.5 and $1.0 \mathrm{~g}$. The analysis of the anions $\mathrm{F}, \mathrm{Cl}, \mathrm{Br}, \mathrm{I}$ and $\mathrm{SO}_{4}$ was performed by ion chromatography ICS 3000 Dionex with column AS20 at LIEC laboratory (Nancy, France). Br was also analysed by LA-ICPMS in a series of representative fluid inclusions using the procedure described by Leisen et al. (2012a).

\subsubsection{LA-ICP-MS}

Results are presented in Electronic Appendix (Appendix 1). This technique allows individual fluid inclusions to be ablated directly through the host mineral, quartz, siderite and barite in the present study. The LA-ICP-MS instrument (GeoRessources laboratory, Nancy, France) comprises a GeoLas excimer laser (ArF, 193 nm, Microlas, Göttingen Germany) and an Agilent 7500c quadrupole ICP-MS equipped with an octopole reaction-cell using $\mathrm{H}_{2}$ gas, and a collision-cell using He gas. The laser beam is focused onto the sample within an ablation cell with a Schwarzschild objective (magnification x25) linked with a CCD camera. Synthetic glass from the National Institute of Standard and Technology (NIST) are used for calibration of the different analysed elements and respective masses (200 pulses at $5 \mathrm{~Hz}$ ). The design as an optical imaging system permits the use of different crater diameters $(24,32$ or $60 \mu \mathrm{m})$ at a constant energy density on the sample, by adjusting an aperture in the laser beam path. $\mathrm{Si}, \mathrm{Na}, \mathrm{K}, \mathrm{Mg}, \mathrm{Ca}, \mathrm{Ba}, \mathrm{Sr}, \mathrm{Mn}, \mathrm{Li}, \mathrm{Fe}, \mathrm{Cu}$ and $\mathrm{Zn}$ were analysed. Concentrations were calculated according to Leisen et al. (2012b).

\subsection{Raman spectroscopy on carbonaceous material}

Since the evolution of the carbonaceous material towards graphite is irreversible, temperatures deduced from the spectra of syntectonic crystals may represent peak-temperature conditions reached by the rocks. The Raman Spectrum of Carbonaceous Material (RSCM) was calibrated as a geothermometer in the range $330-640{ }^{\circ} \mathrm{C}$ (Beyssac et al., 2002, 2004). The RSCM displays one graphite band ( $\mathrm{G}$ band) and several defect-activated bands (D1 and D2 bands) between 1100 and $1800 \mathrm{~cm}^{-1}$ (Beyssac and Lazzeri (2012) which intensities decrease with increasing metamorphic grade. The Raman analysis of graphite-bearing schists was performed on thin sections oriented perpendicular to the foliation and parallel to the lineation by focusing the laser beam beneath a transparent crystal to avoid the effect of amorphisation due to polishing. The Raman spectrometer is a LabRAM HR microspectrometer (Horiba Jobin Yvon) (GeoRessources, Vandœuvre-lès-Nancy) equipped with a 600 gr.mm ${ }^{-1}$ grating and a $\times 100$ objective (Olympus). The excitation beam was provided by a $\mathrm{Ar}^{+}$laser (Stabilite 2017, Newport Corp., Spectra Physics) at $457.9 \mathrm{~nm}$. Laser power was reduced to avoid heating the samples using optical filters of various optical densities, and always lower than $5 \mathrm{~mW}$. The acquisition time was 15 seconds, being each measure repeated 6 times. 10 to 15 spectra were recorded for each sample for statistic purpose. Peak fitting was processed using the Peak Analyser of OriginPro 8.5.1 software. The following expression from Beyssac et al. (2002) was used to derive peak temperature conditions: $\mathrm{T}\left({ }^{\circ} \mathrm{C}\right)=-$ $445 \mathrm{R} 2+641$, with $\mathrm{R} 2$ (peak area ratio) $=(\mathrm{D} 1 /(\mathrm{G}+\mathrm{D} 1+\mathrm{D} 2))$.

\subsection{Stable isotopes}

\subsection{1 $\delta^{18} \mathrm{O} / \delta^{13} \mathrm{C}$ of siderite}

15 to $20 \mathrm{mg}$ of siderite were reacted at $70{ }^{\circ} \mathrm{C}$ with $\mathrm{H}_{3} \mathrm{PO}_{4}$ for 15 days (Scheppard \& Schwarcz, 1970). Isotopic ratio were measured using a modified VG 602D mass spectrometer at the CRPG (Nancy, France) and are reported using conventional $\delta^{18} \mathrm{O}(\mathrm{V}-\mathrm{SMOW})$ and $\delta^{13} \mathrm{C}(\mathrm{V}-\mathrm{PDB})$ notations. The analytical reproducibility is of $\pm 0.1 \%$ for $\delta^{18} \mathrm{O}$ and $\delta^{13} \mathrm{C}$. 


\subsection{2 $\delta^{18} \mathrm{O}$ of quartz}

6.5 to $7.5 \mathrm{mg}$ of quartz (same grains as the ones used for FI analyses) were analysed using the conventional fluorination method (Clayton \& Mayeda, 1963). The measurements were made with a VG SIRA 10 triple-collector instrument at the University of Rennes 1 (France). The analytical reproducibility (estimated from duplicates performed on different Ni fluorination tubes) is of \pm 0.1 $\%$.

\subsection{3 $\delta^{34}$ S of sulphides and sulphates}

Sulfur isotopic composition was measured following the method of Giesemann et al. (1994) at CRPG laboratory (Nancy, France) by EA-IRMS (Elemental Analyser-Isotopic Ratio Mass Spectrometer). $\delta^{34} \mathrm{~S}$ was measured with a GV Instruments Isoprime mass spectrometer coupled in continuous-flow mode to a EuroVector elemental analyser. Results are reported using conventional $\delta^{34} \mathrm{~S}$ (CDT). No inter-sample memory effect was observed. Linearity of the mass spectrometer and reproducibility of the analysis were controlled using CRPG internal reference materials. The analytical reproducibility obtained on the barium sulfate reference material used in CRPG is lower than $0.3 \%$.

\subsection{4 $\delta D$ of white micas}

2 to $3 \mathrm{mg}$ of powdered host-rock were analysed for isotopic composition of hydrogen-bearing minerals, mainly phengites. $\delta \mathrm{D}$ were measured with a $\mathrm{GV}$ Instruments Isoprime mass spectrometer coupled in continuous-flow mode to an EuroVector elemental analyser. No inter-sample memory effect was observed. Linearity of the mass spectrometer and reproducibility of the analysis were controlled using CRPG internal reference materials. The analytical reproducibility obtained on the reference material used in CRPG is better than $0.3 \%$.

\subsection{5 $\delta D$ and $\delta^{18} O$ of fluid inclusions}

Fluids trapped in quartz, barite and siderite crystals were extracted for isotopic analyses by crushing under vacuum. 1.0 to $5.1 \mathrm{~g}$ of millimeter sized grains were loaded into steel tubes and degassed overnight at $120^{\circ} \mathrm{C}$ under vacuum in order to release any water adsorbed at the mineral surface (Dublyansky \& Spötl, 2009). Preliminary tests conducted under the microthermometric heating stage had shown that our fluid inclusions did not decrepitate, nor stretch, for temperatures below $200{ }^{\circ} \mathrm{C} . \mathrm{H}_{2} \mathrm{O}$ was separated cryogenically from other gases and reduced into $\mathrm{H}_{2}$ through a uranium reactor at $800{ }^{\circ} \mathrm{C}$. D/H ratio of $\mathrm{H}_{2}$ was determined by using a dual-inlet VG Micromass 602D mass spectrometer at CRPG (Nancy, France). External reproducibility of D/H measurements was estimated to be lower than $3 \%$ by normalising raw data to the V-SMOW-SLAP scale. Two CRPG water standards were analysed along with each weekly batch of water samples obtained from the fluid inclusions.

To avoid any memory effect on $\mathrm{D} / \mathrm{H}$ ratios within the uranium reactor, samples were systematically duplicated. For each duplicate, $\delta \mathrm{D}$ values from the first extraction were thus not considered, as potentially affected by this memory effect.

$\delta^{18} \mathrm{O}_{\text {fluid }}$ was calculated, for quartz containing primary inclusions, from $\delta^{18} \mathrm{O}_{\text {quartz }}$ using the quartz-water fractionation equation of Zheng (1993a) for a given temperature.

\section{Results}

\subsection{Characteristics of the host-rock}

All sampled veins are hosted within schists composed of phengite, quartz, graphite and rutile. Although not observed in this study, biotite and garnet were also described in these rocks (Álvarez \& Aldaya, 1985) as well as chloritoid (Booth-Rea et al., 2004). The direction of the foliation in the 
West flank of Sierra Almagrera (the studied area) oscillates between N045E and N100E with an average dip around $25-30^{\circ} \mathrm{SE}-\mathrm{S}$ but can reach up to $45^{\circ} \mathrm{SE}-\mathrm{S}$ at El Arteal mine (Figure 1-b). The stretching lineation was not always observed but deformed quartz veins (V-Qtz1) indicate a top to the West shearing (Figure 2-a).

In order to limit either $P$ or $T$ of fluid inclusion isochores, synmetamorphic graphite and white micas (phengite) were analysed. The Raman study of graphitic carbon yielded R2 ratios from 0.12 to 0.21 (mode: $0.18 ; \mathrm{n}=\mathrm{XX}$, in $\mathrm{YY}$ samples), corresponding to temperatures ranging between 545 and $587{ }^{\circ} \mathrm{C}$. These results are in agreement with the temperatures of $535-550{ }^{\circ} \mathrm{C}$ determined with the same method in the Calar Alto unit in the Sierra de Los Filabres (Augier et al., 2005b). Phengite shows Si content from 3.31 to 3.05 a.p.f.u ( $\mathrm{n}=\mathrm{XX}$, in YY samples), corresponding to $2.2 \mathrm{kbar}$ at 545 ${ }^{\circ} \mathrm{C}$ to $9.7 \mathrm{kbar}$ at $587{ }^{\circ} \mathrm{C}$ using equations of Massonne \& Schreyer (1987). This range is similar to $10 \pm 0.7$ kbars to $3.1 \pm 0.3$ kbars, obtained in the Calar-Alto unit in the Sierra de Los Filabres (by Augier et al. (2005b).

\subsection{Vein and fluid inclusion petrography}

According to their geometry, petrography and position relative to host rock foliation, five types of veins are characterized (Table 2). Fluid inclusions found within each vein are described in Table 3.

\begin{tabular}{llll}
$\begin{array}{l}\text { Vein type and } \\
\text { chronology }\end{array}$ & Location & Vein / rock foliation relationships & Vein mineralogy \\
\hline V-Qtz1 & Subsiding area & Parallel to the rock foliation & Quartz (Qtz1) \\
& Mining district & Parallel & Quartz (Qtz1) \\
V-Qtz2 & Subsiding area & Parallel to oblique & Quartz (Qtz2) \\
& Mining district & Parallel to oblique & Quartz (Qtz2) \\
V-Qtz3 & Mining district & Oblique & Quartz (Qtz3), Hematite \\
V-ore & Mining district & Oblique & Siderite, Barite, Quartz Pyrite, \\
& & & Arsenopyrite, Galena ... \\
V-Cal & Subsiding area & Oblique & Calcite \\
\hline
\end{tabular}

Table 2 : Nomenclature, location and description of sampled veins

\subsubsection{V-Qtz1, quartz veins parallel to host-rock foliation}

V-Qtz1 (thickness lower than $30 \mathrm{~cm}$ ) are found in the subsiding area and in the mining district (Figure 2-a). These veins are characterised by quartz high-temperature recrystallisation mechanisms with granoblastic euhedral texture with quartz grains of about $200 \mu \mathrm{m}$ showing triple points with an angle of $120^{\circ}$ in the subsiding area (Figure 2-b) and lobate grain boundaries interpreted as grain boundary migration (Jessell, 1987, Passchier \& Trouw, 2005, Stipp \& Kunze, 2008) in the mining district (Figure 2-c). In the subsiding area, no inclusions were observed in Qtz1 grains. V-Qtz1 from the mining district are crosscut by transgranular fluid inclusion planes, Qtz1-tg1 and Qtz1-tg2 with two distinct orientations (Figure 2-d-e-f; Table 3).

\subsubsection{V-Qtz2, partly parallel quartz veins}

V-Qtz2 (thickness of about $10 \mathrm{~cm}$ ) are oblique regarding the rock foliation along certain sections of the vein while other parts are parallel (Figure 3-a). Since V-Qtz2 partly crosscut the rock foliation they are considered as postdating V-Qtz1, parallel to the foliation. V-Qtz2 are characterized by anhedral quartz grains of about 3-5 $\mathrm{mm}$, showing undulose extinction. These grains are characterized by wave-shaped grain-boundaries and subgrain boundaries. Subgrain rotation and bulging recrystallisation processes could be distinguished (Figure 3-b). Microstructures indicate dynamic recrystallisation at slightly lower temperatures than V-Qtz1 (Figure 3-b; Passchier \& Trouw, (2005)). Fluid inclusions in V-Qtz2 are found within intragranular (Qtz2-ig) (Figure 3-bc) or transgranular planes (Qtz2-tg) (Figure 4-a-b-e). Direction and dip of Qtz2-ig fluid inclusion 
planes are randomly distributed (Figure 3-e) throughout the vein but are parallel to each other within a single grain. This suggests that they are rather related to crystallographic directions reactivated during crystal plastic deformation than to tectonic fracturing. Qtz2-tg are parallel to each other and to the wall of V-Qtz2 (Figure 4-b-e). They were likely produced by crack-and-seal deformation.

\begin{tabular}{|c|c|c|c|c|c|c|c|c|}
\hline $\begin{array}{l}\text { Vein type } \\
\text { and } \\
\text { chronology }\end{array}$ & $\begin{array}{l}\text { Fluid } \\
\text { inclusion } \\
\text { type }\end{array}$ & $\begin{array}{l}\text { Fluid inc } \\
\text { stage } \\
\text { chronolo }\end{array}$ & Ision & $\begin{array}{l}\text { Striking } \\
\text { direction }\end{array}$ & $\begin{array}{l}\text { Size } \\
(\mu \mathrm{m})\end{array}$ & Shape & Filling & $\begin{array}{l}\text { Flw } \\
\text { (vol\%) }\end{array}$ \\
\hline \multirow[t]{3}{*}{ V-Qtz1 } & - & Early & 1 & Grain boundary & $?$ & & $?$ & $?$ \\
\hline & Qtz1-tg1 & Early & 2 & $\mathrm{~N} 130^{\circ}$ & $\sim 20$ & $\begin{array}{l}\text { Equant, } \\
\text { rounded }\end{array}$ & $\begin{array}{l}\mathrm{L}, \mathrm{V}, \text { acc. } \\
\text { calcite }\end{array}$ & $\begin{array}{l}65-75 \\
65-75\end{array}$ \\
\hline & Qtz1-tg2 & Early & 2 & $\mathrm{~N} 000^{\circ}-\mathrm{N} 030^{\circ}$ & $15-25$ & Euhedral & $\mathrm{L}, \mathrm{V}$ & \\
\hline \multirow[t]{2}{*}{ V-Qtz2 } & Qtz2-ig & Early & 2 & Random & $15-25$ & $\begin{array}{l}\text { Euhedral to } \\
\text { dismembered }\end{array}$ & $\mathrm{L}, \mathrm{V}$ & $50-80$ \\
\hline & Qtz2-tg & $\begin{array}{l}\text { Low- } \\
\text { saline }\end{array}$ & 3 & $\mathrm{~N} 000^{\circ}-\mathrm{N} 010^{\circ}$ & $10-15$ & $\begin{array}{l}\text { Equant, } \\
\text { rounded }\end{array}$ & $\mathrm{L}, \mathrm{V}$ & $70-80$ \\
\hline V-Qtz3 & Qtz3-p & Pre-ore & 4 & $\begin{array}{l}\text { Primary } \\
\text { inclusions }\end{array}$ & $>50$ & Elongated & $\mathrm{L}, \mathrm{V}$ & $70-75$ \\
\hline \multirow[t]{3}{*}{ V-ore } & Qtz-ore-tg & Ore & 5 & $\mathrm{~N} 000^{\circ}-\mathrm{N} 010^{\circ}$ & $5-10$ & Euhedral & $\mathrm{L}, \mathrm{V}$ & $70-90$ \\
\hline & Sd-p & “ & 5 & $\begin{array}{l}\text { Primary } \\
\text { (cleavage } \\
\text { planes) }\end{array}$ & $5-20$ & Euhedral, flat & $\mathrm{L}, \mathrm{V}$ & $70-90$ \\
\hline & Brt-p & “ & 5 & $\begin{array}{l}\text { Primary } \\
\text { (cleavage } \\
\text { planes) }\end{array}$ & $30-50$ & $\begin{array}{l}\text { Euhedral, } \\
\text { irregular }\end{array}$ & $\mathrm{L}$ or $\mathrm{L}, \mathrm{V}$ & $65-80$ \\
\hline V-Cal & Cal-p & Late & $?$ & Isolated clusters & $20-70$ & Irregular, flat & $?$ & $80-95$ \\
\hline
\end{tabular}

-tg stands for transgranular, -ig for intragranular and - $p$ for primary

$\mathrm{L}$ : liquid, $\mathrm{V}$ : vapor, acc.: accidentally trapped mineral

Table 3 : Nomenclature, chronology and characteristics of fluid inclusions

\subsubsection{V-Qtz3, oblique veins from the mining district}

V-Qtz3 are composed of euhedral quartz, associated to hematite, that have developed in veins (thickness $<5 \mathrm{~cm}$ ) oblique to the host-rock foliation or in voids. Although euhedral Qtz3 overgrow Qtz2 (Figure 4-b), it is never intersected by Qtz2-tg. Isolated fluid inclusions are interpreted as contemporaneous to crystal growth (Qtz3-p; Figure 4-f). Hematite is found within microfissures extending from the wall rock to Qtz2 (Figure 4-b-d) and in voids between euhedral Qtz3 (Figure 4$a-b)$. The lack of microfracturing affecting Qtz3 and the almost systematic association of Qtz3 and hematite minerals suggest that both minerals grew simultaneously.

\subsubsection{V-ore, oblique mineralised veins from the mining district}

V-ore veins crosscut V-Qtz1 (Figure 5-a), V-Qtz2 and V-Qtz3 (Figure 4-a).The thickness of $\mathrm{V}$-ore can reach several decimetres. They are developed in two main clusters striking N000-160E and N120-130E. The veins may include small clasts of graphitic-schists (Figure 5-b). Microeuhedral quartz $(0.5-1 \mathrm{~mm})$ crystallised on the walls of V-ore (Figure 5-a) prior to siderite formation. Pyrite is included in siderite (Figure 5-c). Arsenopyrite crystals with rhomb facets were incorporated during the last stage of pyrite growth (Figure 5-d). Galena occurs at the contact between siderite and barite (Figure 5-e). Barite is present in the form of small lamella. The complete mineral sequence can be summarised as micro-euhedral quartz-siderite-pyrite-arsenopyrite-galenabarite (Figure 5-f). Qtz-ore-tg are parallel to the wall rock and crosscut several micro-euhedral quartz. Fluid inclusions in siderite and barite are observed along cleavage planes and interpreted as primary (Figure 5-g-h). 


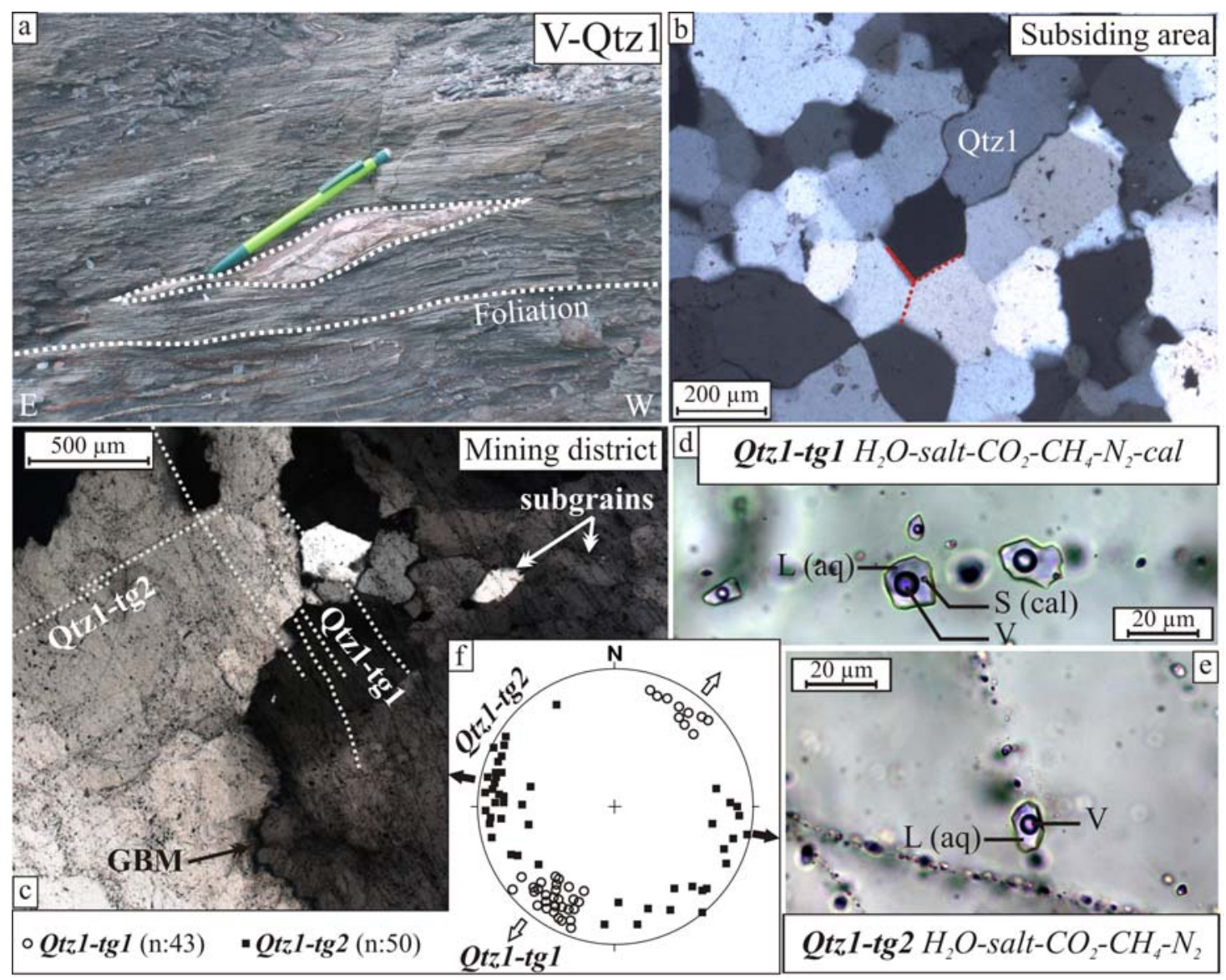

Figure 2 : a) V-Qtz1 quartz vein parallel in the rock foliation. b) Optical microphotograph under cross-polarized light (XPL) showing the petrography of Qtzl: static recrystallization (120 ${ }^{\circ}$ angles) and grain boundary migration recrystallization. c) Qtz1: recrystallized quartz with transgranular FIP. d) Qtz1-tg1 FIP. e) Qtz1-tg2 FIP. f) Poles of Qtz1-tg1 and Qtz1-tg2 FIP represented on lower hemisphere stereogram. Arrows represent the directions of opening. L for liquid, $\mathrm{V}$ for vapor and $\mathrm{S}$ for solid.

\subsubsection{V-Cal, oblique calcite veins from the subsiding area}

These lenticular tension gashes display a length of several centimetres and a few millimetres of opening crosscutting V-Qtz2 (Figure 6-a). Fluid inclusions are found as clusters interpreted as primary (Figure 6-b-c).

\subsection{Microthermometry and Raman results}

Characteristic phase transition temperatures and calculated compositions of fluid inclusions are reported on Table 4 and Figure 7. Individual fluid inclusion measurements are given in Electronic appendix.

\subsubsection{Fluid inclusions in Qtz1}

Salinity of Qtzl-tg1 ranges between 9.7 and 22.6 mass\% eq.NaCl. $T_{\mathrm{h}}(\mathrm{L})$ range between 319 and $350{ }^{\circ} \mathrm{C}$. The volatile phase is predominantly made of $\mathrm{CO}_{2}$ with minor amounts of $\mathrm{CH}_{4}$ and $\mathrm{N}_{2}$.

Salinity of Qtz1-tg2 ranges between 21.6 and 23.8 mass\% eq. $\mathrm{NaCl} . T_{\mathrm{h}}(\mathrm{L})$ range from 305 to $344{ }^{\circ} \mathrm{C}$ (Figure 7, Table 4). The volatile phase is made of $\mathrm{CO}_{2}$ predominantly with minor amounts of $\mathrm{CH}_{4}$ and $\mathrm{N}_{2}$. 

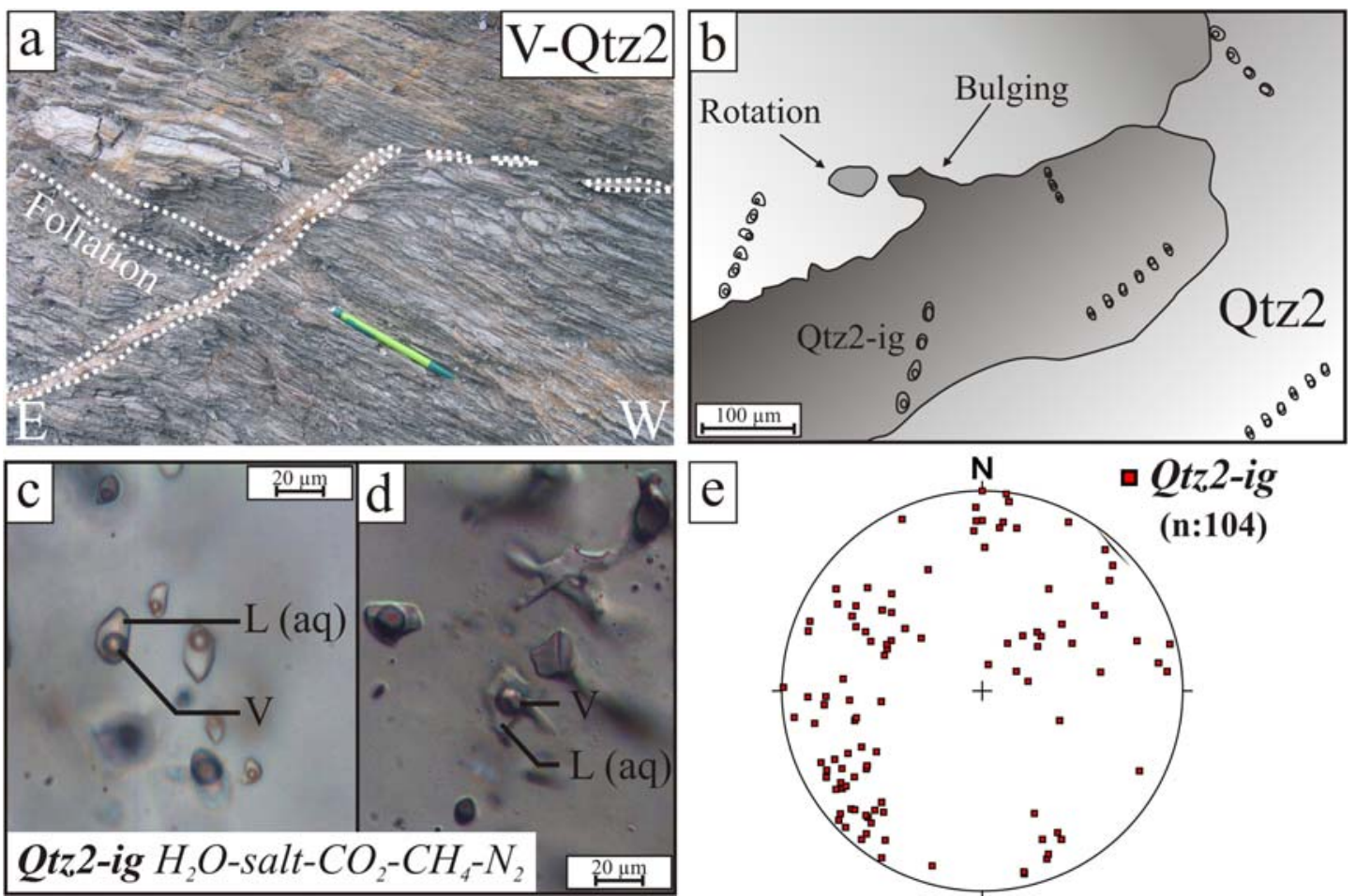

Figure $3:$ a) V-Qtz2 quartz vein locally parallel to the foliation (upper part) while the main section is discordant to the foliation (central part). b) Relationship between petrography of recrystallized quartz (subgrain rotation and bulging) and fluid inclusions. c) Optical microphotographs under plane-polarized light showing intragranular Qtz2-ig FIP. d) Deformed fluid inclusion Qtz2-ig. e) Poles of Qtz2-ig fluid inclusion planes represented on lower hemisphere stereogram.
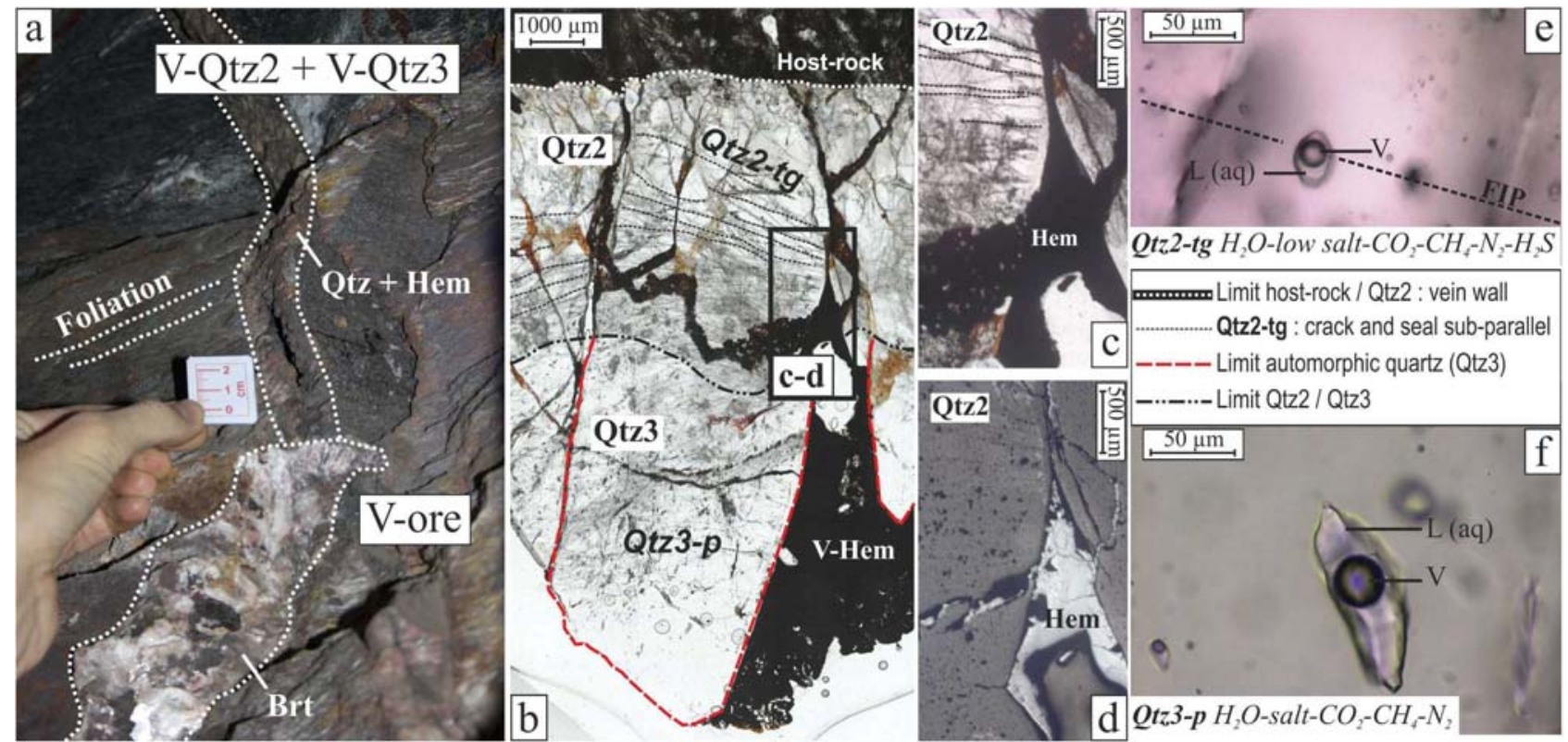

Figure 4 : a) N10E V-Qtz2 discordant to the foliation reopened as V-Qtz3, intersected by V-ore discordant vein. Optical microphotographs under natural light: b) Contact between Qtz2 and Qtz3. Qtz2 grains still show undulose extinction and are affected by Qtz2-tg transgranular FIP. Qtz3 euhedral quartz contain only Qtz3-p primary fluid inclusions. Hematite microfissures affect Qtz2. Hematite also fills open spaces between Qtz3 crystals. c) Zoom of zone localized in b). d) Hematite in reflecting light. e) Qtz2-tg transgranular FIP e) Qtz3-p primary FI. 


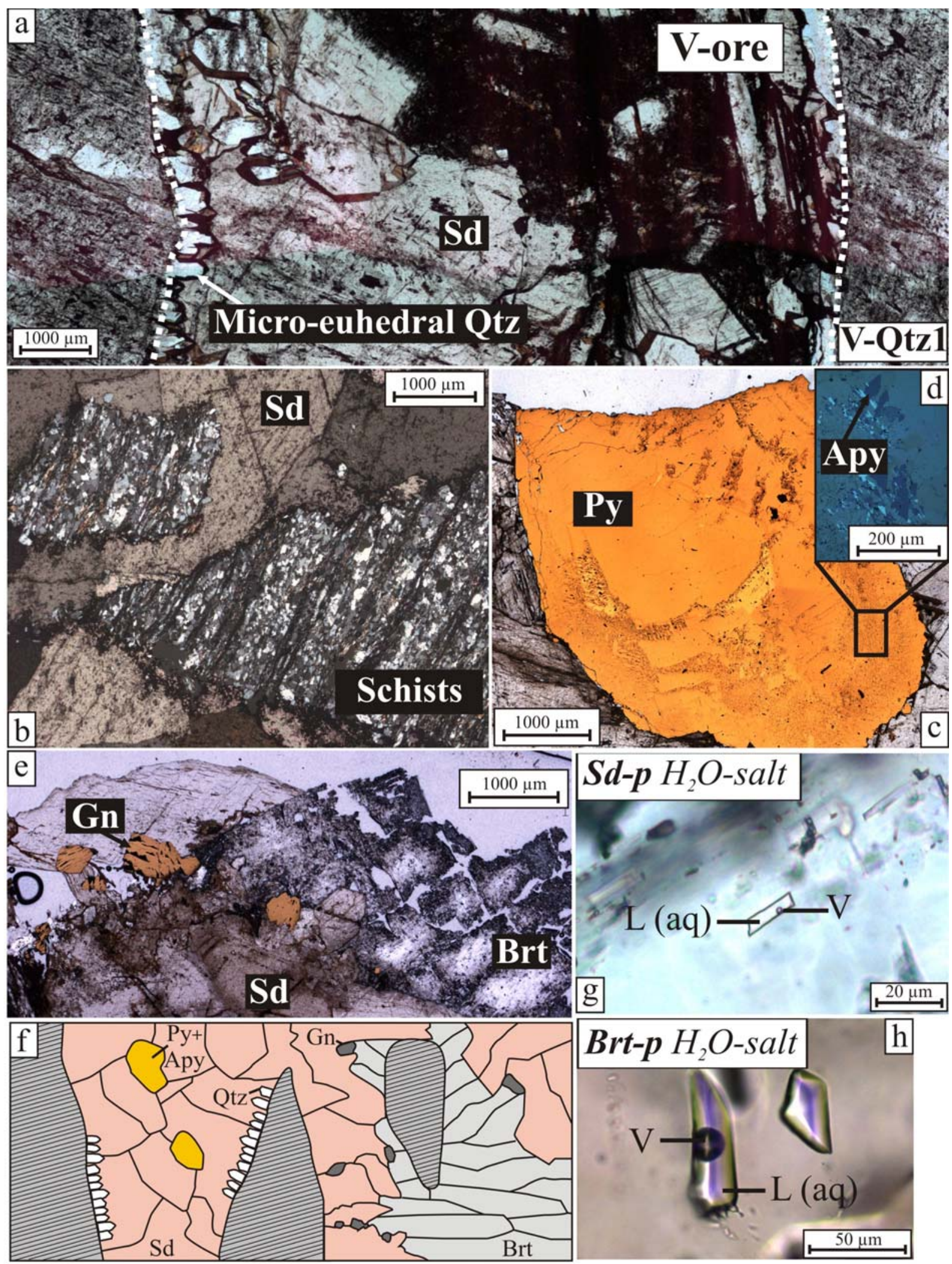

Figure 5 : Optical microphotographs of V-ore and related minerals, in plane-polarized light (PPL), cross-polarized light (XPL) and reflected light (RL). a) Breccia of graphitic chloritoid-schists cemented by siderite (XPL). b) Growth stage within pyrite and location of microphotograph "c" (PPL+RL). c) Arsenopyrite in the last stage of pyrite growth (PPL+ RL). d) Micro-euhedral quartz and siderite vein crosscut Qtz1 (PPL). e) Sequence of siderite, galena and barite (PPL+ RL). f) Schematic representation of the relationship between the various minerals in V-ore. g) Sd-p primary fluid inclusion in siderite. h) Brt-p primary FI in barite. 

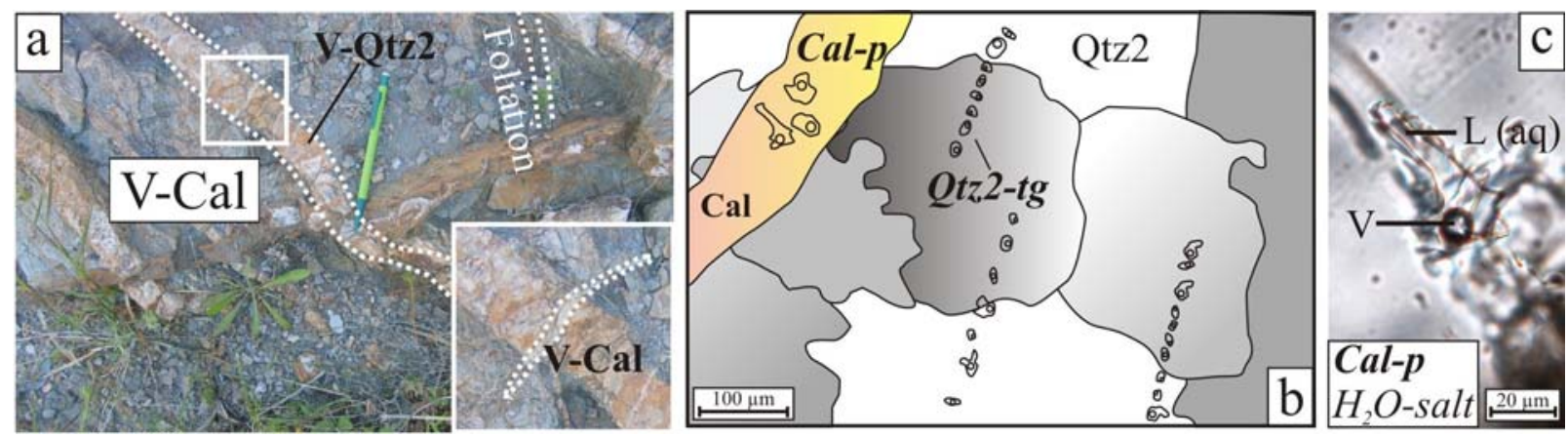

Figure 6 : a) V-Qtz2 discordant quartz vein intersected by V-Cal discordant calcite vein. b) Relationships between VQtz2 grains, Qtz2-tg transgranular FIT and calcite vein containing Cal-p primary FI. c) detail of Cal-p FI.

\subsubsection{Fluid inclusions in Qtz2}

Salinity of Qtz2-ig ranges between 11.9 and 20.6 mass\% eq. NaCl. $T_{\mathrm{h}}(\mathrm{L})$ occurred between 220 and $400{ }^{\circ} \mathrm{C}$ (Figure 7, Table 4). This high scatter of homogenisation temperature is directly linked to plastic deformation of fluid inclusions (Vityk et al., 1995, Bodnar, 2003, Diamond et al., 2010). Therefore, only $T_{\mathrm{h}}$ of intact inclusions with the smallest gas bubbles (flw $>65$ vol\%) are considered, resulting in a range between 220 and $355^{\circ} \mathrm{C}$. . The volatile phase is dominated by of $\mathrm{CO}_{2}$ with minor amounts of $\mathrm{CH}_{4}$ and $\mathrm{N}_{2}$.

Salinity of Qtz2-tg ranges between 0.1 and 2.4 mass\% eq.NaCl. $T_{\mathrm{h}}(\mathrm{L})$ range between 290 and $330{ }^{\circ} \mathrm{C}$ (Figure 7, Table 4). Raman spectroscopy showed that the volatile phase is predominantly made of $\mathrm{CO}_{2}$ with presence of $\mathrm{CH}_{4}, \mathrm{~N}_{2}$ and $\mathrm{H}_{2} \mathrm{~S}$.

\subsubsection{Fluid inclusions in Qtz3}

Salinity of Qtz3-p ranges between 12.7 and 20.9 mass\% eq.NaCl (Figure 7, Table 4). $T_{\mathrm{h}}$ (L) range between 235 and $310{ }^{\circ} \mathrm{C}$. The volatile is phase made of $\mathrm{CO}_{2}$ predominantly with $\mathrm{CH}_{4}$ and $\mathrm{N}_{2}$ in minor amounts.

\subsubsection{Fluid inclusions in Qtz, Sd and Brt from V-ore veins}

Salinity of Qtz-ore-tg ranges between 13.0 and 17.0 mass\% eq.NaCl. Methane (traces) is the only gas present. $T_{\mathrm{h}}(\mathrm{L})$ range between 150 and $248{ }^{\circ} \mathrm{C}$ (Figure 7, Table 4).

Salinity of Sd-p ranges between 15.4 and 24.6 mass\% eq. NaCl. Because no hydrohalite melting nor dissociation temperature of clathrate could be observed, our calculations are only based on the final ice melting and take not into account the complexity of the fluid system. Therefore some data show salinity higher than halite saturation in the $\mathrm{H}_{2} \mathrm{O}-\mathrm{NaCl}$ system. $T_{\mathrm{h}}(\mathrm{L})$ was observed between 110 and $222{ }^{\circ} \mathrm{C}$ (Figure 7, Table 4). Such a high variation could be attributed to leakage within this highly cleavable mineral (Bodnar, 2003). Raman spectroscopy showed that $\mathrm{CH}_{4}$ was the only component in the gas phase.

Salinity of Brt-p ranges between 20.7 and 25.8 mass\% eq.NaCl. Again, because hydrohalite could never be observed, our calculations only take into account $T_{\mathrm{m}}$ (ice) and the complexity of the system is not expressed. Therefore, some of our data show salinity higher than $\mathrm{NaCl}$ saturation in the $\mathrm{H}_{2} \mathrm{O}-\mathrm{NaCl}$ system. $T_{\mathrm{h}}(\mathrm{L})$ was observed between 237 and $335^{\circ} \mathrm{C}$ (Figure 7, Table 4). Although, the inclusions were carefully checked before and after measurements, leakage before microthermometric experiments can not be excluded (Ulrich \& Bodnar, 1988, Bodnar, 2003) and these values should be discussed very carefully. Raman spectroscopy showed that the volatile phase is predominantly made of $\mathrm{CO}_{2}$ (however in small amount) with minor $\mathrm{CH}_{4}$ and $\mathrm{N}_{2}$.

\subsubsection{Fluid inclusions in calcite from $\mathrm{V}$-Cal}

Salinity of Cal-p ranges between 11.8 and 18.4 mass $\%$ eq. NaCl. $T_{\mathrm{h}}(\mathrm{L})$ ranged between 67 and $87^{\circ} \mathrm{C}$ (Figure 7). Raman spectroscopy did not permit to identify the nature of the gas phase. 


\begin{tabular}{|c|c|c|c|c|c|c|c|c|c|c|c|c|}
\hline \multirow[b]{2}{*}{$\begin{array}{l}\text { Fluid } \\
\text { inclusion }\end{array}$} & \multicolumn{5}{|c|}{ Microthermometry } & \multicolumn{7}{|c|}{ Calculated composition } \\
\hline & $\begin{array}{c}T_{\mathrm{e}} \\
\left({ }^{\circ} \mathrm{C}\right)\end{array}$ & $\begin{array}{c}T_{\mathrm{m}}(\text { Ice }) \\
\left({ }^{\circ} \mathrm{C}\right)\end{array}$ & $\begin{array}{c}T_{\mathrm{m}}(\mathrm{Cla}) \\
\left({ }^{\circ} \mathrm{C}\right)\end{array}$ & $\begin{array}{c}T_{\mathrm{h}} \\
\left({ }^{\circ} \mathrm{C}\right)\end{array}$ & $\begin{array}{c}\text { Salinity } \\
\text { (mass\% eq. } \\
\mathrm{NaCl} \text { ) }\end{array}$ & $\begin{array}{c}V_{\mathrm{m}} \\
\left(\mathrm{cm}^{3} / \mathrm{mol}\right)\end{array}$ & $\begin{array}{c}\mathrm{H}_{2} \mathrm{O} \\
(\mathrm{mol} \%)\end{array}$ & $\begin{array}{c}\mathrm{CO}_{2} \\
(\mathrm{~mol} \%)\end{array}$ & $\begin{array}{c}\mathrm{CH}_{4} \\
(\mathrm{~mol} \%)\end{array}$ & $\begin{array}{c}\mathrm{N}_{2} \\
(\mathrm{~mol} \%)\end{array}$ & $\begin{array}{c}\mathrm{H}_{2} \mathrm{~S} \\
\left(\mathrm{~mol}^{\circ}\right)\end{array}$ & $\begin{array}{c}\mathrm{NaCl} \\
(\mathrm{mol} \%)\end{array}$ \\
\hline Qtz1-tg1 & $\begin{array}{c}-48.6 /- \\
39.8 \\
-45.2\end{array}$ & $\begin{array}{c}-22.7 /- \\
7.7 \\
-14.5\end{array}$ & $\begin{array}{c}-3.8 / 6.5 \\
6.0\end{array}$ & $\begin{array}{c}319 / 350 \\
330\end{array}$ & $\begin{array}{c}9.7 / 22.6 \\
15.0\end{array}$ & $\begin{array}{c}23.1 / 29.2 \\
27.2\end{array}$ & $\begin{array}{c}85.2 / 88.1 \\
87.0\end{array}$ & $\begin{array}{c}1.9 / 3.6 \\
2.8\end{array}$ & $\begin{array}{c}0.01 / 0.1 \\
0.08\end{array}$ & $\begin{array}{c}0.01 / 0.05 \\
0.03\end{array}$ & - & $\begin{array}{c}9.5 / 11.3 \\
10.1\end{array}$ \\
\hline Qtz1-tg2 & $\begin{array}{c}-64.6 /- \\
39.8 \\
-55.1\end{array}$ & $\begin{array}{c}-23.1 /- \\
17.6 \\
-22.5\end{array}$ & $\begin{array}{c}-5.7 /-2.3 \\
-3.2\end{array}$ & $\begin{array}{c}305 / 344 \\
320\end{array}$ & $\begin{array}{c}21.6 / 23.8 \\
23.0\end{array}$ & $\begin{array}{c}22.8 / 25.6 \\
23.4\end{array}$ & $\begin{array}{c}80.7 / 84.2 \\
81.0\end{array}$ & $\begin{array}{c}2.8 / 5.2 \\
3.3\end{array}$ & $\begin{array}{c}0.01 / 0.3 \\
0.1\end{array}$ & $\begin{array}{c}0.01 / 0.06 \\
0.04\end{array}$ & - & $\begin{array}{c}12.3 / 16.4 \\
15.6\end{array}$ \\
\hline Qtz2-ig & $\begin{array}{c}-45.7 /- \\
30.9 \\
-35.0\end{array}$ & $\begin{array}{c}-20.0 /-8.4 \\
-16.0\end{array}$ & $\begin{array}{c}-2.5 /-1.1 \\
-2.1\end{array}$ & $\begin{array}{c}220 / 355 \\
340\end{array}$ & $\begin{array}{c}11.9 / 20.6 \\
17.0\end{array}$ & $\begin{array}{c}25.3 / 30.0 \\
27.1\end{array}$ & $\begin{array}{c}82.3 / 89.1 \\
85.0\end{array}$ & $\begin{array}{c}2.4 / 5.6 \\
3.0\end{array}$ & $\begin{array}{c}0.01 / 0.3 \\
0.2\end{array}$ & $\begin{array}{c}0.01 / 0.07 \\
0.02\end{array}$ & - & $\begin{array}{c}10.1 / 12.8 \\
11.8\end{array}$ \\
\hline Qtz2-tg & - & $\begin{array}{c}-3.0 /-0.7 \\
-1.5\end{array}$ & $\begin{array}{c}7.3 / 12.3 \\
9.8\end{array}$ & $\begin{array}{c}290 / 330 \\
300\end{array}$ & $\begin{array}{c}0.1 / 2.4 \\
1.2\end{array}$ & $\begin{array}{c}20.5 / 27.0 \\
25.3\end{array}$ & $\begin{array}{c}92.3 / 96.2 \\
95.0\end{array}$ & $\begin{array}{c}2.5 / 4.1 \\
3.0\end{array}$ & $\begin{array}{c}0.01 / 0.2 \\
0.1\end{array}$ & $\begin{array}{c}0.05 / 0.3 \\
0.1\end{array}$ & $\begin{array}{c}0.03 / 0.07 \\
0.05\end{array}$ & $\begin{array}{c}0.1 / 2.5 \\
1.8\end{array}$ \\
\hline Qtz3-p & - & $\begin{array}{c}-21.7 /-9.0 \\
-17.3\end{array}$ & $\begin{array}{c}-2.7 /-1.2 \\
-1.8\end{array}$ & $\begin{array}{c}189 / 308 \\
265\end{array}$ & $\begin{array}{c}12.7 / 20.9 \\
18.3\end{array}$ & $\begin{array}{c}20.7 / 23.0 \\
22.6\end{array}$ & $\begin{array}{c}89.2 / 94.1 \\
91.0\end{array}$ & $\begin{array}{c}1.2 / 3.2 \\
2.5\end{array}$ & $\begin{array}{c}0.01 / 0.1 \\
0.05\end{array}$ & $\begin{array}{c}0.01 / 0.06 \\
0.04\end{array}$ & - & $\begin{array}{c}5.2 / 8.8 \\
6.4\end{array}$ \\
\hline Qtz-ore-tg & $\begin{array}{c}-49.6 /- \\
39.6 \\
-45.0\end{array}$ & $\begin{array}{c}-24.3 /- \\
14.7 \\
-21.2\end{array}$ & - & $\begin{array}{c}150 / 248 \\
210\end{array}$ & $\begin{array}{c}18.4 / 25 \\
23\end{array}$ & $\begin{array}{c}19.6 / 21.5 \\
20.5\end{array}$ & $\begin{array}{c}83.0 / 87.0 \\
85.0\end{array}$ & - & Trace & - & - & $\begin{array}{c}13.0 / 17.0 \\
15.0\end{array}$ \\
\hline Sd-p & $\begin{array}{c}-49.0 /- \\
40.1 \\
-44.3\end{array}$ & $\begin{array}{c}-23.5 /- \\
11.4 \\
-23.2\end{array}$ & - & $\begin{array}{c}110 / 222 \\
190\end{array}$ & $\begin{array}{c}15.4 / 24.6 \\
24.1\end{array}$ & $\begin{array}{c}18.8 / 20.9 \\
19.4\end{array}$ & $\begin{array}{c}80.3 / 85.6 \\
83.0\end{array}$ & - & Trace & - & - & $\begin{array}{c}15.2 / 18.3 \\
17.0\end{array}$ \\
\hline Brt-p & $\begin{array}{c}-59.1 /- \\
41.6 \\
-56.2\end{array}$ & $\begin{array}{c}-25.3 /- \\
17.7 \\
-22.4\end{array}$ & - & $\begin{array}{c}237 / 335 \\
305\end{array}$ & $\begin{array}{c}20.7 / 25.8 \\
23.0\end{array}$ & $\begin{array}{c}21.0 / 24.0 \\
23.0\end{array}$ & $\begin{array}{c}80.1 / 84.6 \\
82.0\end{array}$ & Trace & Trace & Trace & - & $\begin{array}{c}12.3 / 19.2 \\
18.0\end{array}$ \\
\hline Cal-p & - & $\begin{array}{c}-15.0 /-8.0 \\
-14.0\end{array}$ & - & $\begin{array}{c}67 / 87 \\
80\end{array}$ & $\begin{array}{c}11.8 / 18.4 \\
17.0\end{array}$ & $\begin{array}{c}18.6 / 18.9 \\
18.7\end{array}$ & $\begin{array}{c}87.2 / 89.1 \\
88.0\end{array}$ & - & - & - & - & $\begin{array}{c}10.4 / 13.1 \\
12.0\end{array}$ \\
\hline
\end{tabular}

Table 4 : Microthermometric and compositional data for all generations of fluid inclusions from the Sierra Almagrera, (mode data in italics) 


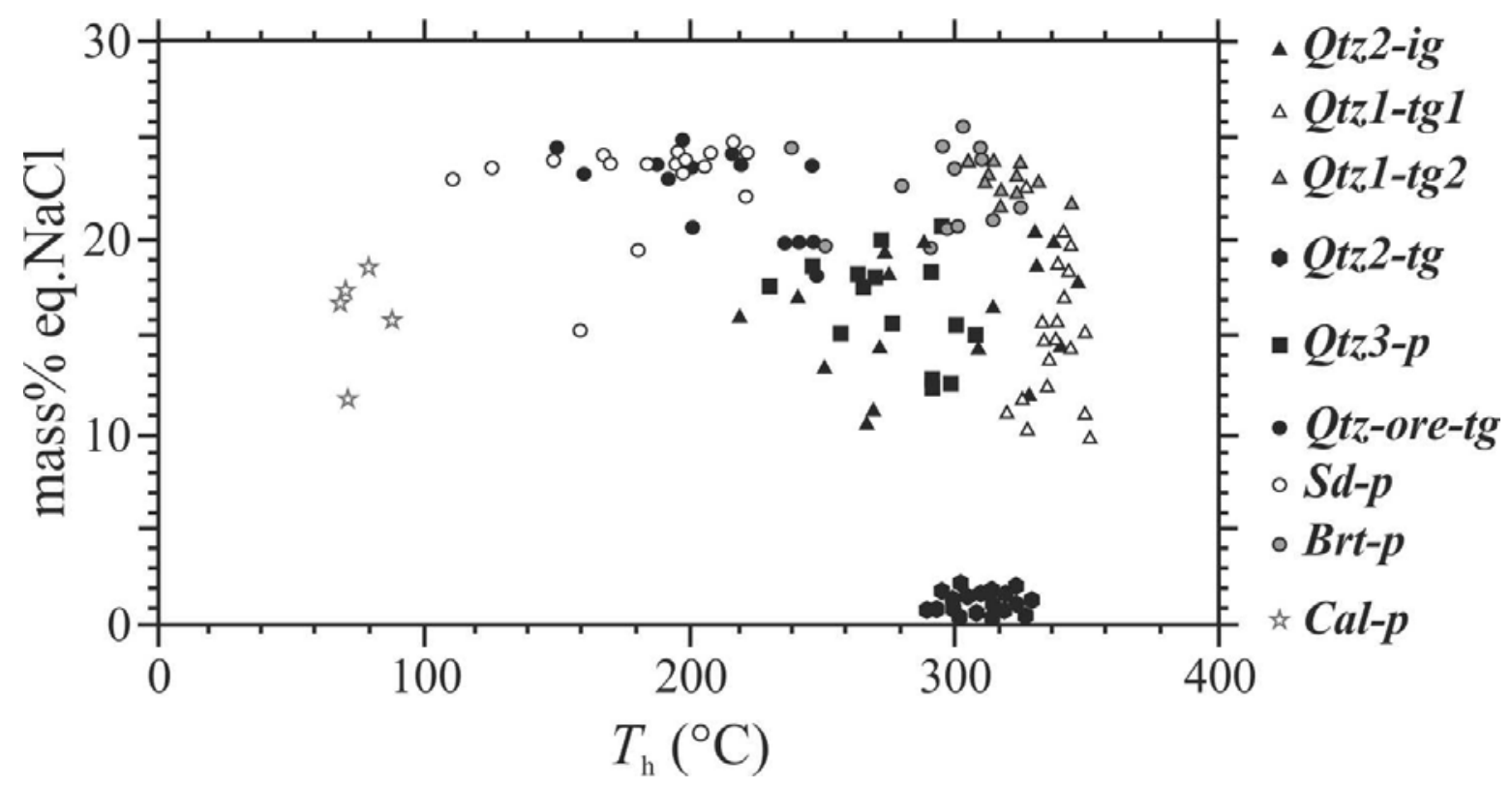

Figure 7 : Microthermometric data and salinities for all stages of fluid inclusions from the Sierra Almagrera

\subsection{Halogen chemistry}

V-Qtz1 analysed Qtz1-tg1, Qtz1-tg2 and certainly fluid inclusions located on grain boundaries. A Cl/Br molar ratio of 1000 was measured by crush-leach and LA-ICPMS and a chlorinity of $4200 \mathrm{mmol} / \mathrm{kg}$ solution (Figure 8 ).

Sd-p and Brt-p displayed a $\mathrm{Cl} / \mathrm{Br}$ ratio between 3500 and 10000 and a chlorinity between 4200 and $5400 \mathrm{mmol} / \mathrm{kg}$ solution, respectively. The $\mathrm{Cl} / \mathrm{Br}$ ratio of Brt-p obtained with LA-ICP-MS is between 1200 and 4500 . The other generations of fluids did not give interpretable signal.

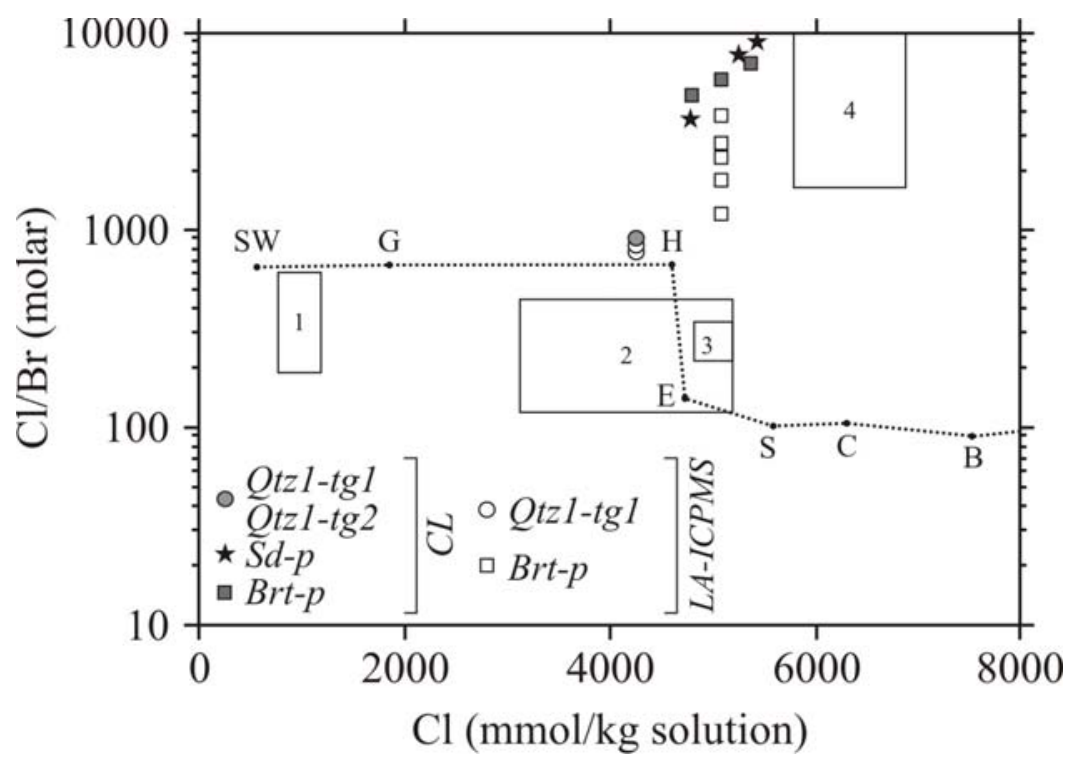

Figure $8: \mathrm{Cl} / \mathrm{Br}$ molar ratio versus $\mathrm{Cl}$ concentrations for fluid inclusions analysed both by LA-ICP-MS (empty symbols) and crush-leach methods (CL, full symbols) (samples from the mining district). The seawater evaporation trend is mentioned (Fontes \& Matray, 1993): SW: Seawater, G: Gypsum, H: Halite, E: Epsomite, S: Sylvite, C: Carnallite, B: Bischofite. Comparison data (crush-leach analysis) 1 to $4: 1$-Variscan fluids equilibrated with host rocks (granite and metamorphic rocks), (Boiron et al., 2003), 2-Primary brines issued from Triassic evaporites in Pyrenees (Mccaig et al., 2000), 3-Primary brines from Ag deposits in Morocco (Essarraj et al., 2005), 4-Secondary brines associated to emerald mineralization in Columbia (Banks et al., 2000). 


\subsection{Stable isotope measurements}

$\delta^{13} \mathrm{C}$ siderite range between -9.5 and $-10.9 \%$ V-PDB $(n=4) . \delta^{18} \mathrm{O}$ siderite range between 20.6 and $22.5 \%$ V-SMOw (Table 5). $\delta^{18} \mathrm{O}$ barite range from 13.0 to $13.2 \%$ v-Smow $(\mathrm{n}=2), \delta^{34} \mathrm{~S}(\mathrm{n}=4)$ from 19.4 to $23.1 \%$ V-CDT.Pyrite $(\mathrm{n}=3)$ display $\delta^{34} \mathrm{~S}$ between 5.4 and $6.4 \%$ V-CDT. Galena $(\mathrm{n}=3)$ display $\delta^{34} \mathrm{~S}$ between -2.4 and $8.3 \%$ V-CDT.

$\delta^{18} \mathrm{O}$ of fluid inclusion bearing minerals are given in Table $5 . \delta \mathrm{D}$ of white micas of the hostrock yielded values of $-52 \pm 1 \%$. $\delta \mathrm{D}_{\text {fluid }}$ from Qtzl sampled in the subsiding zone (quartz devoid visible inclusions) range between -33 and $-36 \%$ v-smow (Table 5). In the mining district, V-Qtz1 host Qtz1-tg1 and Qtz1-tg2. The $\delta \mathrm{D}$ values of transgranular fluid inclusion planes between -28 and $-32 \%$ v-sMow include $\delta \mathrm{D}$ of possible earlier fluids displaced to grain boundaries during quartz recrystallisation (Table 5).

$\delta \mathrm{D}_{\text {fluid }}$ from Qtz2-ig and Qtz3-p are quite similar between -23 and $-36 \%$ v-smow (Table 5, Figure 9). $\delta \mathrm{D}_{\text {fluid }}$ from Qtz2-tg (selected section with Qtz2-tg dominant in the quartz grains) display a larger range of values between -17 and $-48 \%$ V-SMow (Table 5, Figure 9).

$\mathrm{V}$-ore were significantly more D-depleted. $\delta \mathrm{D}_{\text {fluid }}$ of Sd-p range between -65 and $-80 \% \mathrm{~V}$ smow. $\delta D_{\text {fluid }}$ of Brt-p ranged between -53 and $-69 \%$ v-smow (Table 5, Figure 9 ).

\begin{tabular}{|c|c|c|c|c|c|c|c|}
\hline $\begin{array}{l}\text { Vein } \\
\text { type }\end{array}$ & $\begin{array}{c}\text { Fluid } \\
\text { inclusion type } \\
\end{array}$ & $\begin{array}{c}\text { Fluid } \\
\text { inclusion } \\
\text { stage }\end{array}$ & $\begin{array}{c}\delta^{18} \mathrm{O}_{\text {host }} \\
(\mathrm{V}-\mathrm{SMOW} \\
\% \mathrm{o}) \\
\text { min }-\max \\
(n) \\
\text { median } \\
\end{array}$ & $\begin{array}{c}T_{\text {trapping }}{ }^{(1)} \\
\left({ }^{\circ} \mathrm{C}\right)\end{array}$ & $\begin{array}{c}\delta^{18} \mathrm{O}_{\text {fluid }}{ }^{(2)} \\
(\mathrm{V}-\mathrm{SMOW} \\
\% \text { ) } \\
\text { min - } \max \\
\text { median }\end{array}$ & $\begin{array}{c}\delta \mathrm{D}_{\text {fluid }} \\
(\mathrm{V}-\mathrm{SMOW} \\
\% \text { o } \\
\text { min to max } \\
\text { (n) } \\
\text { median }\end{array}$ & $\begin{array}{c}T_{\text {equilibrium }}^{(3)} \\
\left({ }^{\circ} \mathrm{C}\right)\end{array}$ \\
\hline V-Qtz1 & $\begin{array}{c}\text { Grain } \\
\text { boundary }\end{array}$ & Early & $\begin{array}{c}16.5-16.7 \\
(2) \\
16.6\end{array}$ & ? & ? & $\begin{array}{c}-33 \text { to }-36 \\
\text { (2) } \\
-34.5\end{array}$ & $488-520$ \\
\hline V-Qtz1 & Qtz1-tg1+tg2 & Early & $\begin{array}{c}15.9-17.2 \\
\text { (2) } \\
16.6\end{array}$ & $440-480$ & $?$ & $\begin{array}{c}-28 \text { to }-30 \\
\text { (2) } \\
-29.0\end{array}$ & $442-478$ \\
\hline V-Qtz2 & Qtz2-ig & Early & $\begin{array}{c}16.2-17.0(4) \\
16.5\end{array}$ & $400-520$ & $\begin{array}{c}11.7-14.2 \\
12.8\end{array}$ & $\begin{array}{c}-23 \text { to }-36(4) \\
-30.0\end{array}$ & $404-520$ \\
\hline V-Qtz2 & Qtz2-tg & Low-saline & $\begin{array}{c}15.9-17.6(7) \\
16.6\end{array}$ & $300-560$ & $?$ & $\begin{array}{c}-17 \text { to }-48(7) \\
-34.0\end{array}$ & $365-704$ \\
\hline V-Qtz3 & Qtz3-p & Pre-ore & $\begin{array}{c}14.0-14.5(2) \\
14.3\end{array}$ & $250-380$ & $\begin{array}{c}5.0-9.6 \\
7.4\end{array}$ & $\begin{array}{c}-30(1) \\
-30\end{array}$ & 459 \\
\hline V-ore & Sd-p & Ore & $\begin{array}{c}20.6-22.5(4) \\
21.5\end{array}$ & $120-260$ & $\begin{array}{c}3.2-14.5 \\
8.8\end{array}$ & $\begin{array}{c}-65 \text { to }-80(4) \\
-71.5\end{array}$ & $>1630$ \\
\hline V-ore & Brt-p & Ore & $\begin{array}{c}13.0-13.2(2) \\
13.1\end{array}$ & $280-440$ & $\begin{array}{c}8.2-11.3 \\
9.7\end{array}$ & $\begin{array}{c}-53 \text { to }-69(7) \\
-58.0\end{array}$ & $831-1025$ \\
\hline
\end{tabular}

(1) Obtained from isochore intersection with PT-path

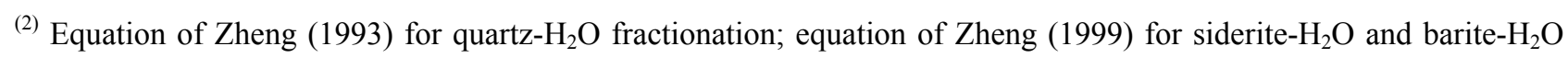
fractionation

${ }^{(3)}$ Equation of Suzuoki and Epstein (1976) for muscovite- $\mathrm{H}_{2} \mathrm{O}$ fractionation between $\delta \mathrm{D}_{\text {fluid }}$ and $\delta \mathrm{D}_{\text {host-rock }}=-52 \%$

Table 5 : Isotopic data for various stages of fluid inclusions from the Sierra Almagrera 


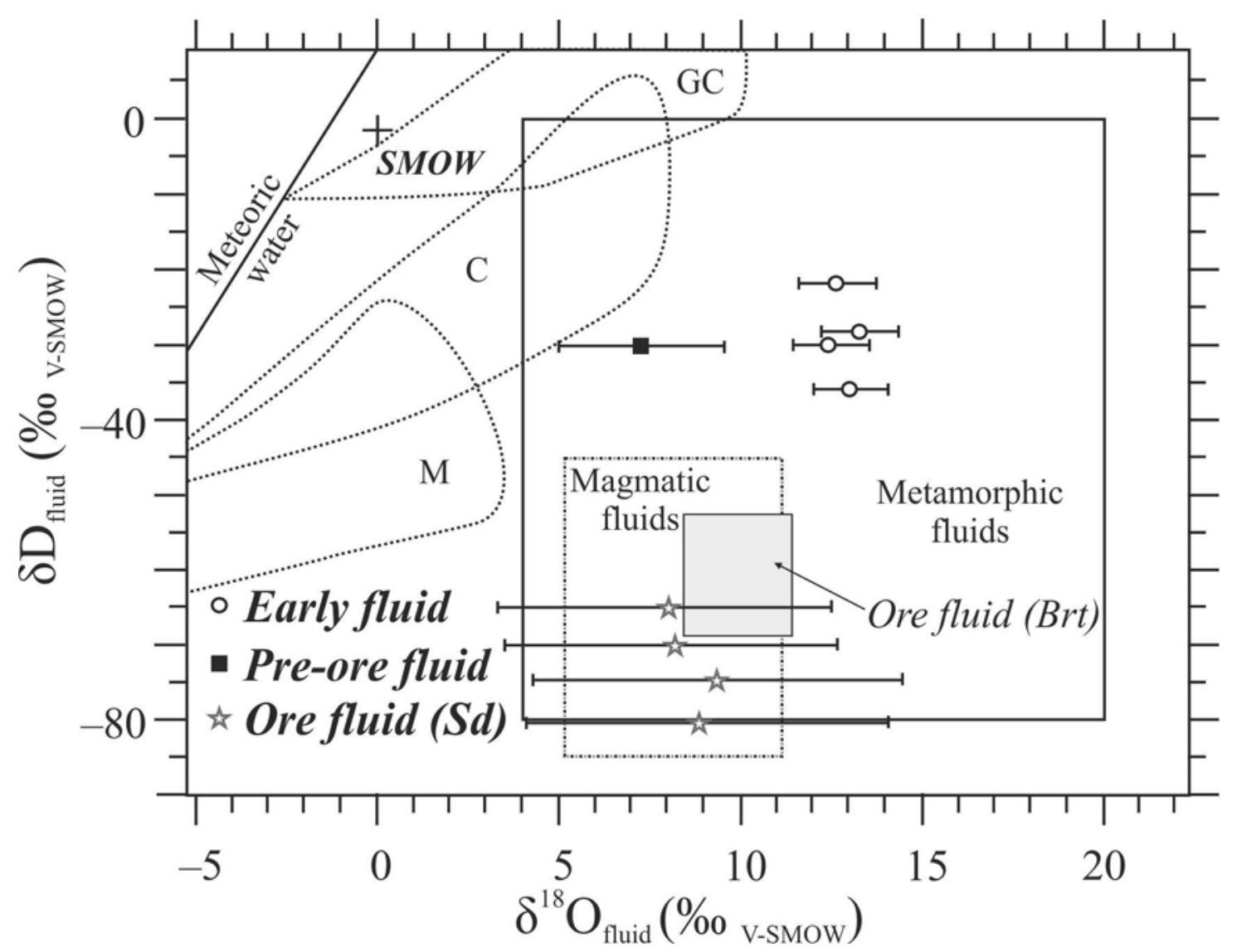

Figure $9: \delta^{18} \mathrm{O}_{\text {fluid }} \%$ V-Smow and $\delta \mathrm{D}_{\text {fluid }} \%$ v-smow of fluid early stage, pre-ore and ore fluid stage (Sd). Field of some representative fluids from literature: basinal fluids (Sheppard (1986): GC = Gulf Coast; $\mathrm{C}=\mathrm{California}$; $\mathrm{M}=\mathrm{Michigan}$ ). Metamorphic and magmatic fluids boxes are plotted from Field and Fifarek (1985).

\section{Discussion}

Successive tectonic, magmatic and hydrothermal stages were experienced during the geologic history of the Sierra Almagrera, directly impacting the behaviour of the crustal fluid reservoirs. The fluids circulating during the different stages of deformation of the metamorphic rocks from the Sierra Almagrera have been trapped in a sequence of veins composed of quartz, siderite, barite and calcite. The metamorphic fluid reservoir under lithostatic conditions is usually separated from the overlying brittle reservoir under hydrostatic conditions by the brittle-ductile transition. Although the change in rheology is not strictly a hydrogeological barrier, the permeability increases gradually in the upper part of the crust (Manning \& Ingebritsen, 1999, Ingebritsen \& Manning, 2002). As a consequence, deeper and shallower reservoirs may behave independently on both sides of the brittle-ductile transition or be connected by particular tectonic pathways with high permeability. The deeper metamorphic reservoir may be disturbed by ascending magmatic or mantellic fluid input but descending fluid penetrating from the upper crustal reservoir is usually limited to the brittleductile transition zone (Famin \& Nakashima, 2004). Surface fluids may range from non-saline water (usually meteoric water) to hypersaline fluids (brines) related to evaporitic conditions.

\subsection{Paleofluid sequence}

\subsubsection{Key criteria to build up the fluid sequence}

Early fluid stage: Although no fluid inclusions were observed within V-Qtzl sampled in the subsiding zone, crushing techniques permitted to extract a fluid, analysed for its $\delta \mathrm{D}$. This likely suggests that fluid inclusions trapped prior to plastic deformation have been displaced towards grain 
boundaries during recrystallisation processes (Kerrich, 1976, Wilkins \& Barkas, 1978, Johnson \& Hollister, 1995) and partly preserved. The calculated equilibrium temperature, based on $\mathrm{H}$ fractionation, between this fluid and host-rock is comprised between 488 and $520{ }^{\circ} \mathrm{C}$, in agreement with ductile conditions. Plastically deformed or dismembered inclusions are found within intragranular planes of V-Qtz2 (Qtz2-ig) and non-deformed inclusions are found within transgranular planes of V-Qtz1. The latter result from healing of former open cracks (Lespinasse, 1999, Lespinasse et al., 2005) and thus more brittle conditions are required than for intragranular planes. As a consequence, Qtz2-ig formed at conditions more ductile than Qtz1-tg1,2. Ductile deformation affecting V-Qtz1 and V-Qtz2 in the Sierra Almagrera are compatible with a top-to-the $\mathrm{W} /$ top-to-the SW extensional shearing similar to those described within the Sierra de los Filabres (Augier et al., 2005c) (Figure 1). The youngest ductile extensional stages recognised within the metamorphic pile are dated at $14 \mathrm{Ma}$ (Gomez-Pugnaire et al., 2004, Platt et al., 2006, GomezPugnaire et al., 2012).

Similar microthermometric phase transitions were observed for Qtz2-ig and Qtz1-tg1,2 (average $T_{\mathrm{h}}$ around $340{ }^{\circ} \mathrm{C}$ and comparable maximum salinity) (Figure 7). This suggests that both veins trapped the same fluid after the vein formation (V-Qtz1) or during the vein formation with a fluid circulating between the quartz grains of the veins (V-Qtz2). The dominant NW-SE direction of Qtz1-tg1 may be coherent with late Tortonian shortening directions associated to strike-slip tectonics (Montenat \& Ott D'estevou, 1990). In such a case, the transgranular fluid inclusion planes would correspond to a stage without any relation with the top-to-the-W, top to the SW ductile shearing evidences observed in the host-rock. This would mean that the fluid inclusion planes formed while the Sierra Almagrera was in the brittle domain under hydrostatic conditions. Another interpretation could be to relate the directions of these fluid inclusion planes to an ongoing extensional tectonics corresponding to a top to the SW ductile shearing. In such a case, the transgranular planes would correspond to local brittle ruptures within a structural ductile domain still controlled by lithostatic conditions.

Low-saline fluid stage: Qtz2-tg are characterised by a much lower salinity than all other fluid inclusions observed in this study. Qtz2-tg never affect V-Qtz3 nor V-Cal. This suggests an episodic arrival of low-saline fluid after the formation of V-Qtz2 but prior to V-Qtz3 and V-Cal. The subsequent exhumation within the brittle domain was coeval with an uplift of mountain ranges as revealed by the development of deltaic to shallow sea deposits in the Huercal-Overa and Vera basins during early Tortonian (Figure 1) (Weijermars, 1985, Booth-Rea et al., 2003). This uplift was associated to a local NS extension (Augier et al., 2005a)) or to the onset of transcurrent tectonics (Montenat \& Ott D'estevou, 1990)). Whatever could be the associated tectonic regime, the paleotopography provides indicative data about possible hydrogeological conditions within the brittle crust at that time.

Pre-ore fluid stage: Euhedral Qtz3 is contemporaneous of the formation of hematite. Primary Qtz3-p were trapped during V-Qtz3 formation. The obliquity with respect to the host-rock foliation and the lack of undulose extinction in the euhedral quartz shows that V-Qtz3 formed within the brittle domain.

Ore fluid stage: V-ore crosscut V-Qtz3 (Figure 4-a). Higher salinity can be observed either in fluid inclusions found in transgranular planes within early micro-euhedral quartz (Qtz-ore-tg) that developed on the wall-rock or in primary fluid inclusions found in siderite and barite (Sd-p and Brtp). Quartz and siderite trapped fluids at lower temperature conditions $\left(T_{\mathrm{h}}\right.$ of $\mathrm{Sd}-\mathrm{p}$ around $\left.190{ }^{\circ} \mathrm{C}\right)$ than stage $3\left(T_{\mathrm{h}}\right.$ of Qtz3-p around $\left.265^{\circ} \mathrm{C}\right)$. V-ore vein sets have two main orientations: N000EN340E and N120E-N130E. The N-S direction is coherent with Messinian direction of horizontal shortening and E-W direction of extension, related to a major transcurrent activity of the Palomares Fault Zone.

Late fluid stage: Inclusions in calcite recorded lower $T_{\mathrm{h}}$ around $80^{\circ} \mathrm{C}$, suggesting a formation at more superficial position. Its relative chronology in the fluid sequence could be debated since it has not been sampled in the same structural block as V-ore veins. The only chronologic criterion is the crosscutting geometry with V-Qtz2. 


\subsubsection{P-V $-T-X$}

Raman spectrometry study of graphitic schists constrained the maximal temperature experienced by the host-rock at $545-587^{\circ} \mathrm{C}$.

$P-T$ ranges of fluid inclusion entrapment are constrained by the isochores and the geothermal gradients (Figure 10). For the Sierra Almagrera, geothermal gradient data are poorly documented. The only data available comes from the Sierra Nevada located to the West of Sierra Almagrera. A gradient of $60{ }^{\circ} \mathrm{C} / \mathrm{km}$ under lithostatic conditions is indicated for the final stages under ductile conditions (Gomez-Pugnaire \& Fernandez-Soler, 1987, Bakker et al., 1989, Jabaloy et al., 1993, Augier et al., 2005b). A gradient of $30{ }^{\circ} \mathrm{C} / \mathrm{km}$ corresponding to the anorogenic european average gradient was arbitrarily taken as higher limit.

Early fluid stage: There is no strict evidence that entrapment of Qtz2-ig occurred under lithostatic or hydrostatic pressure. However, inclusion shapes range from euhedral to dismembered (Tarantola et al., 2010, 2012) with large variations of the gas filling ratio. This is indicative for plastic deformation and would thus rather be related to lithostatic pressure conditions.

Transgranular fluid inclusion planes Qtz1-tg1, 2 indicate brittle behaviour within the quartz vein, but the mica-rich host-rock may still be affected by ductile deformation. Qtz1-tg1,2 could also have been trapped under hydrostatic or lithostatic regime. A rather large $T$ and $P$ range thus result for trapping conditions of inclusions related to Early fluid stage without any significant difference between Qtz2-ig (400 to $520^{\circ} \mathrm{C}$ and 270 to $380 \mathrm{MPa}$ ) and Qtz1-tg1,2 (440 to $480{ }^{\circ} \mathrm{C}$ and 110 to 230 $\mathrm{MPa}$ ) (Figure 10).

Low-saline fluid stage: There is no evidence whether transgranular Qtz2-tg planes formed under lithostatic or hydrostatic fluid regime. However, the fact that they show preferred orientation (NS) would rather be coherent with lithostatic pressure. The trapping conditions for these fluid inclusions range from 300 to $560{ }^{\circ} \mathrm{C}$ and 40 to $240 \mathrm{MPa}$ (Figure 10).

Pre-ore fluid stage: Since the euhedral quartz Qtz3 were no more affected by ductile deformation and recrystallisation processes, it is considered that they crystallised in the brittle domain under hydrostatic pressure, within the following $P-T$ range: 250 to $380{ }^{\circ} \mathrm{C}$ and 40 to 120 MPa (Figure 10).

Ore fluid stage: Crystallisation of quartz, siderite and barite occurred in an open system. Hydrostatic conditions permit to constrain the $T$ - $P$ range of entrapment for fluid inclusions in Qtzore-tg at 160 to $300{ }^{\circ} \mathrm{C}$ and 30 to $90 \mathrm{MPa}$ and in Sd-p at 120 to $260{ }^{\circ} \mathrm{C}$ and 20 to $80 \mathrm{MPa}$ (Figure 10). Unfortunately the confidence on microthermometric data obtained on barite is low (Ulrich $\&$ Bodnar, 1988). The observed homogenisation temperatures would imply a significant increase of the trapping temperature at 280 to $440{ }^{\circ} \mathrm{C}$ for 40 to $130 \mathrm{MPa}$. This could be explained by the active volcanism, but also be an over interpretation of stretched inclusions in barite.

Late fluid stage: Calcite stage is characterised by lower homogenisation temperatures suggesting a cooling of the system down 70 to $110{ }^{\circ} \mathrm{C}$ under 10 to $30 \mathrm{MPa}$ hydrostatic pressure (Figure 10).

\subsubsection{Source of fluids}

The fluids associated to the geology and tectonic of this presently outcropping part of the Sierra Almagrera are recorded in different veins: i) V-Qtz1, parallel to the foliation, characterised by grain boundary migration recrystallisation indicating dynamic recrystallisation at high temperature and static recrystallisation evidences. This reveals the transposition of the veins while the host-rock was in the ductile domain; ii) Postdating V-Qtz2 display sections oblique to the foliation suggesting that they were less deformed during the ductile extension than V-Qtz1. The oblique sections show bulging and subgrain rotation recrystallisation evidence that occurred at lower temperature than grain boundary migration recrystallisation e.g. (Passchier \& Trouw, 2005). These features, as well as undulose extinction, suggest ongoing dynamic deformation affecting VQtz2 at the brittle-ductile transition; iii) Late stages are recorded by oblique V-Qtz3, V-ore, V-Cal formed within the brittle domain. 

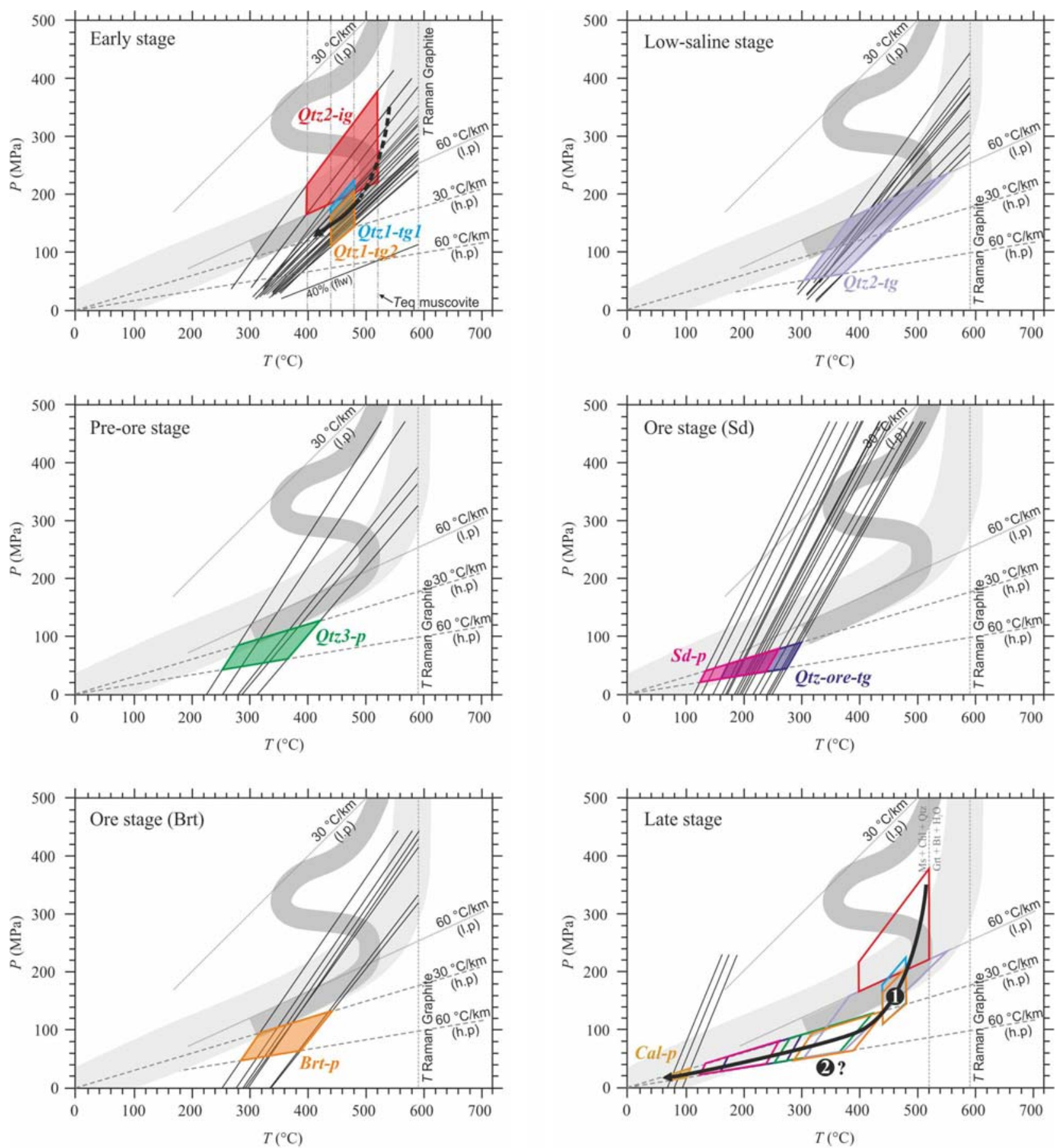

(1) Retrograde evolution

Range of $P$ - $T$ trapping conditions

$P-T$ path (De Jong, 1992)

$P-T$ path (Augier, 2005)

- Retrograde $P$ - $T$ path inferred from

2 Thermal pulse related to $\mathrm{Pb}-\mathrm{Ba}$ mineralization probably related magmatism at depth? fluid inclusions

Figure 10:P (MPa) versus $T\left({ }^{\circ} \mathrm{C}\right)$ for all stages of fluids from the Sierra Almagrera. 1.p.: geothermal gradient at lithostatic pressure; h.p.: geothermal gradient at hydrostatic pressure.

Early fluid stage: Hydrogen isotope fractionation shows equilibrium between fluid inclusions of the Early fluid stage and mica-rich host-rock. Indeed the calculated temperatures are in the order $400-520{ }^{\circ} \mathrm{C}$, comparable with the temperatures obtained from isochores and geothermal gradients. 
The range of homogenisation temperatures of Qtz1-tg1,2 is smaller than Qtz2-ig, suggesting that the inclusions were less affected by plastic deformation. This may be indicative of the passage through the brittle-ductile transition.

Halogen signatures of Qtzl grains plot along the seawater evaporation trend in agreement with halite evaporation. The ages around $14 \mathrm{Ma}$ for ductile features related to the Miocene extensional tectonics are much older than the age of formation of late Messinian evaporites. So, only the Triassic evaporites could be concerned by these dissolution processes. Presently, local remnants of gypsum tectonic slices are preserved to the North of the Sierra Almagrera. However, because $\mathrm{Br}$ is highly incompatible in halite, secondary brines would yield a fluid depleted in $\mathrm{Br}$. In our case, as shown by hydrogen isotope, there must be equilibrium between the fluid and graphitic schists enriching the fluid in $\mathrm{Br}$ (Yardley, 2005).

The variability trend in salinity in both Qtz2-ig and Qtz1-tg1,2 might either reflect i) an original heterogeneity related to discontinuous interaction with Triassic evaporates, ii) the effect of plastic deformation for Qtz2-ig (Diamond et al., 2010) or iii) a mixing between deep highly saline fluid and a low salinity fluid end-member.

Low-saline fluid : Fluid isotopic values obtained on Qtz2 grains containing Qtz2-tg also take into account the signature of fluids of the Early stage. $\delta D_{\text {fluid }}$ values ranging from -17 to $-48 \%$ are generally lower than values of the Early fluid stage. $\delta \mathrm{D}$ values of the dilute fluid are thus $\mathrm{D}$ depleted compared to those of the Early stage, with values likely not buffered by the host-rock. This suggests the input of an external, low-saline fluid, from the upper reservoir.

Either the volume of low-saline fluids was sufficient to dilute high salinity fluids from the Early stage or more likely the lower ductile and the upper brittle reservoirs were not connected during exhumation and behave independently. The penetration of low-saline fluids could be likely associated to the uplift of mountain ranges during the Serravalian and the early Tortonian (Martínez-Martínez \& Azañón, 2002, Platt, 2007) (Figure 11). However, in the absence of $\delta^{18} \mathrm{O}$ values and interpretable LA-ICP-MS values, it cannot be concluded whether this fluid is of meteoric or basinal origin.

Pre-ore fluid stage: Hydrogen isotopic composition is not controlled by the host-rock (Table 5). The enrichment of iron in the fluid led also to the formation of hematite in the open spaces between Qtz3 crystals (Figure 4-b, Figure 11). This stage corresponds to tectonic conditions in the brittle domain

The salinity is comparable as the Early fluid stage. $\delta^{18} \mathrm{O}_{\text {quartz }}$ is lower than for the Early stage and trapping temperatures allow defining a $\delta \mathrm{D} / \delta^{18} \mathrm{O}_{\text {fluid }}$ signature shifted towards basinal/meteoric water compositions. These data are coherent with a mixing between low-saline basinal/meteoric and with an upward migration of underlying high salinity fluids (Early fluid stage) enriched in iron. This may correspond to the onset of transcurrent tectonics during this period and the beginning of the volcanism (Figure 11).

Ore fluid stage: Although slightly lower in $\delta^{13} \mathrm{C}$ (about $2 \%$ ) and slightly higher in $\delta^{18} \mathrm{O}$ (about $1 \%$ ), siderite from the El Arteal in the mining district could be compared with the data of siderite from Jaroso Ravine (Figure 1-b) and interpreted as indicative for meteoric water and low temperature hydrothermal conditions Martinez-Frias et al. (2007). However the $\delta^{13} \mathrm{C}$ may also be buffered during fluid interaction with the metasedimentary sequence whatever their origin.

The combination of $\delta \mathrm{D}$ and $\delta^{18} \mathrm{O}$ values result in a fluid with a magmatic or metamorphic signature (Field \& Fifarek, 1985). These results do not fit with the meteoric water line (Figure 9) and would infirm the conclusions from Martinez-Frias et al. (2007). On the other hand, $\delta \mathrm{D}_{\text {fluid }}$ are strongly in disequilibrium with the host-rock and imply an external source for this fluid.

Fluids in siderite were trapped at lower temperatures than the previous fluid stages and thus at shallower conditions (Figure 11). They display higher values of salinity than earlier stages, reaching up to 25 mass\% eq. $\mathrm{NaCl}$ (Figure 7, Table 4). $\mathrm{Cl} / \mathrm{Br}$ data shows that the fluid is $\mathrm{Br}$ depleted and far from the sea water evaporation trend. As $\mathrm{Br}$ is not easily incorporated in halite, dissolution of halite would yield this type of fluid. Chlorine/Bromine ratios thus indicate signatures that could be 
compared to secondary brines (Banks et al., 2000) resulting from dissolution of evaporites (Figure 8).

The strong salinity increase might result from a combination of volcanism in the Palomares Fault Zone as suggested by $\delta \mathrm{D}$ and $\delta^{18} \mathrm{O}$ values (Figure 9), and dissolution of evaporites as suggested by their halogen signatures (Figure 8). The direction of the veins is coherent with the Messinian strike-slip regime related to a major activity of the Palomares Fault Zone (Montenat et al., 1987, Booth-Rea et al., 2004). In addition to the dissolution of Triassic evaporites, dissolution of Messinian marginal evaporites (deposited from 5.96 to $5.67 \mathrm{Ma}$ ) (Clauzon et al., 1996) is a possible scenario (Figure 11). These Messinian evaporates preceded the main sea-level drop related to the peak of the salinity crisis. Pre-incision Messinian evaporitic deposits were available as revealed by the "Formation à blocs" from the Vera basin which reworked Messinian early gypsum during the main incision (Figure 11) (Clauzon, 1980, Clauzon et al., 1996). Messinian sediments from Las Herrerias (Figure 1) were mineralised prior to the main Messinian incision and confirm the age of the event (Alvado, 1986, Fortuin et al., 1995, Booth-Rea et al., 2004) (Figure 11).

A subsequent increase of temperature at constant salinity is not to be excluded by fluid trapping conditions in barite exceeding $400{ }^{\circ} \mathrm{C}$ during ore stage. This thermal pulse related to $\mathrm{Pb}-\mathrm{Ba}$ mineralisation could be approximately synchronous with the Miocene volcanism in the area (i.e $\sim 6$ $\mathrm{Ma}$ ) (Figure 11). We suggest high $\mathrm{K}$ and lamproite magmatism to be related with this fluid stage and mineralisation process and to be also a possible metal source. The high $\mathrm{K}$ content or metal such $\mathrm{Zn}$ or $\mathrm{Cu}$ in fluid inclusions also support this hypothesis.

$\delta^{34} \mathrm{~S}$ values of barite are comparable with those of Miocene sulfate sea water (Claypool et al., 1980). The increase of salinity of the ore stage could be related to secondary brines linked to the dissolution of Messinian evaporites.

Late fluid stage: Homogenisation temperatures of fluid inclusions within calcite around $80{ }^{\circ} \mathrm{C}$ could suggest a deep burial or a shallow expression of hot fluids. The salinity of these fluids may be compared with salinity of Early and pre-ore stages. Calcite veins may correspond to a shallower expression of deeper fluid flows presently measured in veins from the uplifted mining district block (Figure 11). In such a case the superficial equivalent in the central block may have been eroded during the subsequent uplift. A second hypothesis is that these calcite veins only developed at a later stage at a lower temperature.

\subsection{RedOx conditions and fluid reservoir}

Fluids trapped as fluid inclusion planes during the Early stage are characterised by a rather low density of the volatile phase dominated by $\mathrm{CO}_{2}$. The significant presence of $\mathrm{CH}_{4}$ (around $20 \%$ of the volatile molar composition) is not that strictly expected in the case of water-graphite equilibrium (Dubessy, 1984, Huizenga, 2001, 2011). Such kind of distribution of volatiles is rather common in metamorphic environments at around $350-450{ }^{\circ} \mathrm{C}$ where local equilibrium between water and graphite is reached, and contribute then, through mixing with other fluids, to the rather common metamorphic signature found in most retrograde fluids during exhumation (Cathelineau et al., 1993, Boiron et al., 2003). At lower temperatures, in presence of graphite, $\mathrm{CH}_{4}$ is expected to be the dominant species if redox conditions are rather reducing. This is the case for the predominance of $\mathrm{CH}_{4}$ in fluid inclusions during the precipitation of siderite at the beginning of the Ore stage which occurred with a $T_{\mathrm{h}}$ around $190^{\circ} \mathrm{C}$. This precipitation from $\mathrm{Fe}^{2+}$ rich solutions needs a rather significant low $\mathrm{fO}_{2}$ and an increase in the $\mathrm{fCO}_{2}$. 


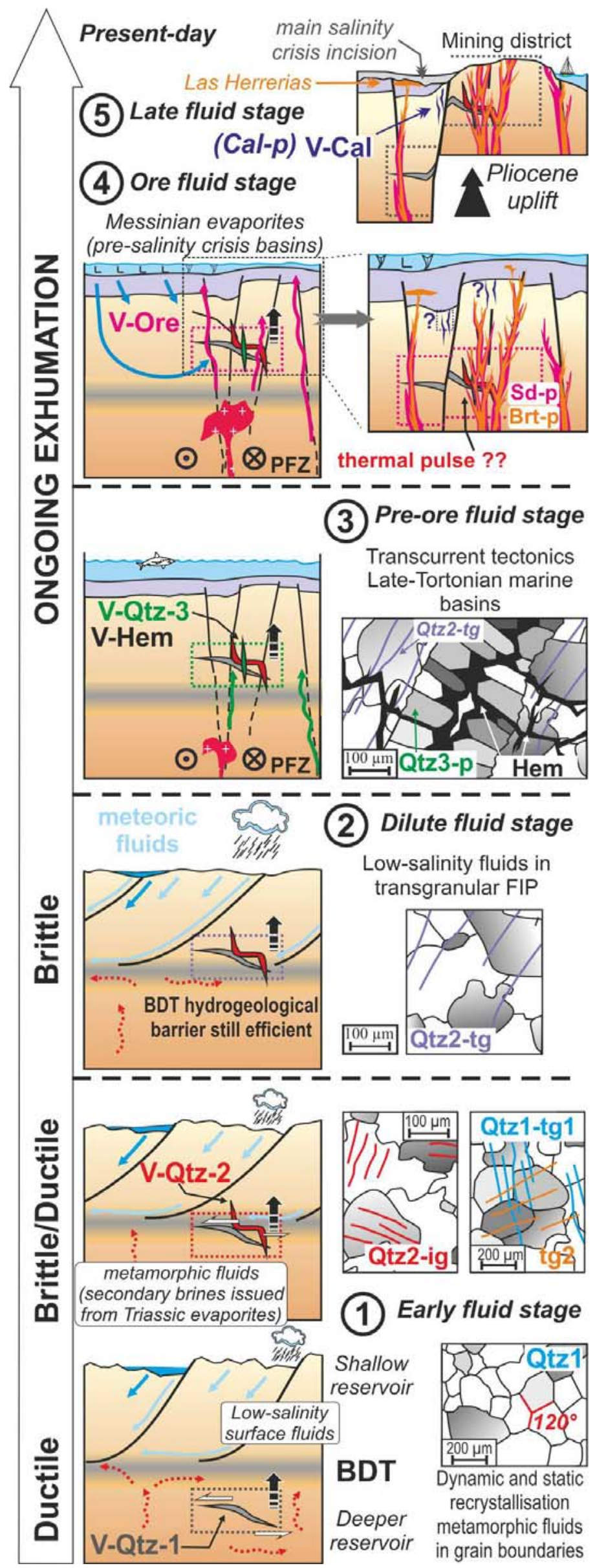

Figure 11: Exhumation of the Sierra Almagrera and associated tectonics, paleo-orographic evolution and paleofluid sequence 
Low-saline and Pre-ore stages show variations in the redox conditions. Low-salinity fluids recorded an increase in $\mathrm{CH}_{4}$ concentrations reaching 30\% and about $10 \%$ of $\mathrm{H}_{2} \mathrm{~S}$. $\mathrm{CO}_{2}$ was again the dominant volatile during V-Qtz3 crystallisation and hematite formed during this Pre-ore stage, attesting for significant oxidising conditions prior to the ore fluid stage where sulphides then sulphates (barite) precipitated. $\mathrm{CO}_{2}$ was then lacking in fluids trapped during the siderite $\left(\mathrm{FeCO}_{3}\right)$ pyrite crystallisation under reduced conditions but was again the dominant low density volatile species in the brine related to the (galena)-barite stage. During oxidising stages, fluids are not buffered at all by local equilibrium, and a part of the fluids are necessarily coming from oxidised fluid reservoirs. It is highly possible that most minerals precipitated through mixing processes. Thus, iron is present as hematite, then siderite, and finally pyrite. In all cases, iron needs to be transported by a reducing fluid at the $\mathrm{Fe}^{2+}$ state. The iron minerals precipitate either as oxides if the conditions become oxidising, as siderite if $\mathrm{P}\left(\mathrm{CO}_{2}\right)$ is sufficiently high and as pyrite if $\mathrm{fS}_{2}$ is increased. All these variations in the iron mineralogy are indicative of significant changes in the physical-chemical conditions all along the process of opening and cementation of fractures. All described changes in volatile composition are recorded within a series of brines trapped in the same system of veins crosscutting the graphitic schists. These fluctuations in the volatile composition and redox conditions need open systems where fluids entering the black schist formation are either buffered by the local reducing conditions (for instance, during the siderite stage), or not buffered at all.

Since both hematite related to V-Qtz3 and siderite from V-ore veins are encountered at close distance in the same gallery, recent transformation due to a general supergene alteration could not be evoked. If the mineral did not precipitate first as hematite under oxidising conditions, the oxidation of a first Fe mineral formed under reducing conditions must have nevertheless occurred prior to the formation of siderite from $\mathrm{V}$-ore veins.

\section{Conclusions}

The characterisation of fluid inclusions trapped within the described veins permit to observe fluids trapped at different position within an exhumating sierra. The general $P-T$ path is characterised by the evolution from lithostatic to hydrostatic pressure. After the low-saline event, all fluids were trapped in minerals crystallising in open structures under hydrostatic pressure. During the exhumation, different contexts associated to fluid circulation are to be considered: i) a first step during which the host-rock passed through the brittle-ductile transition, thus recording metamorphic fluids, ii) a second step occurred when the host-rock entered definitively the brittle domain and predominantly collected upper fluids and, iii) a last step, related to ore formation and maybe magmatism, resulting in a complete tectonic change that modified the relative hydrogeologic independence between the deeper and upper reservoirs.

More generally, the local tectonic geology of the Sierra Almagrera leads to consider two stages for fluid circulation. Prior to transcurrent tectonics, metamorphic rocks from the Sierra Almagrera exhumed as a whole and both V-Qtz1 and V-Qtz2 developed at all places. The onset of transcurrent regimes had two consequences: i) it localised the deformation and associated fluid pathways within the brittle crust and, ii) the occurrence of local transtension and transpression led to the final exhumation of the central area corresponding to the mining district where V-Qtz3 and Vore veins are found.

The first record of the exhumation is characterised by ductile-brittle deformation related to extensional tectonics. During that Early stage, metamorphic brines were interpreted as the result of dissolution of Triassic evaporites. Low-saline fluids were then recorded as the structural unit progressively penetrated within the brittle domain. These fluids are characterised by a loss in major elements such as $\mathrm{K}, \mathrm{Li}, \mathrm{Na}, \mathrm{Mn}, \mathrm{Fe}, \mathrm{Sr}$ and $\mathrm{Ba}$ (Appendix 1) and are not in equilibrium with the host-rock anymore. These low-salinity fluids are likely related to penetration of basinal or meteoric 
waters from the surface favoured by a hydraulic gradient related to uplifted mountain ranges during late Serravalian to early Tortonian times.

These characteristics for the upper fluids could have lasted until present-day exposure but the geodynamic change related to the onset of the Trans-Alboran tectono-volcanism modified the hydrogeological decoupling between the lower and upper reservoirs. Pre-ore stage is characterised by the occurrence of brittle quartz veins related with intermediate salinity and homogenisation temperatures, between meteoric or basinal fluids and upward migration of underlying high salinity fluids (Early fluid stage). The fluids have a volatile phase dominated by $\mathrm{CO}_{2}$ without $\mathrm{CH}_{4}$ and are associated with a 5 times increase of Fe (Appendix 1) which is expressed by the formation of hematite under oxidising conditions. This Pre-ore stage shall be the first evidence of the volcanism.

Reduced conditions prevailed at a later stage of iron-rich fluid migration. This is revealed by the formation of siderite and iron sulphides in the mining district and is related to the activity of the Palomares sinistral fault zone during the Messinian. A second type of brines (Ore stage) shows infiltration of fluids which have dissolved Messinian evaporites of the Vera Basin. These are at the origin of ore mineralisation in veins. The process evolved towards more oxidising conditions associated with a possible thermal pulse that led to the formation of galena and barite whose $\delta^{34} \mathrm{~S}$ signature confirms the involvement of Miocene brines.

The overall evolution of fluid migration in this part of the Betic Cordillera points out the role of three main driving forces: i) an exhumation path related to a global cooling, ii) a drastic change to transcurrent tectonics associated to hydrogeological connections at depth favouring the ascent of hot hydrothermal fluids disturbing the cooling path and, iii) the involvement of two types of secondary brines, one from the deep reservoir implying Triassic evaporites and a more recent one from the Messinian at the surface which might have caused the migration and concentration of economic elements. The interference between these factors influenced the redox conditions within the upper brittle reservoir leading to an alternation of oxidising and reducing conditions that influenced the formation of iron-rich minerals (hematite then siderite-pyrite/arsenopyrite). Deep penetration of late oxidising Messinian secondary brines related to the crystallisation of barite reveal large convection cells from surface to deep aquifers associated to transtensional tectonics and local heat flows, presumed to be related to Miocene magmatism at depth. 


\begin{tabular}{|c|c|c|c|c|c|c|c|c|c|c|c|}
\hline Type of fluid & $\operatorname{Li}(7)$ & $\mathrm{Na}(23)$ & $\operatorname{Mg}(24)$ & $\mathrm{K}(39)$ & $\mathrm{Ca}(43)$ & $\operatorname{Mn}(55)$ & $\mathrm{Fe}(57)$ & $\mathrm{Cu}(63)$ & $\mathrm{Zn}(66)$ & $\operatorname{Sr}(88)$ & $\mathrm{Ba}(137)$ \\
\hline \multirow[t]{14}{*}{ Qtz1-tg1 } & 156 & 82662 & 1713 & 2584 & - & 1603 & 451 & 30 & 48 & 2190 & 48 \\
\hline & 36 & 24046 & 348 & 982 & 21 & 535 & 97 & - & 41 & 634 & 23 \\
\hline & 64 & 54798 & 2676 & 1487 & 43 & 485 & 274 & 27 & 60 & 743 & 22 \\
\hline & 165 & 73518 & 3935 & 4525 & 155 & 353 & 14 & 15 & 164 & 1260 & 21 \\
\hline & 117 & 77775 & 41700 & 4371 & 77 & 1837 & 283 & 41 & 99 & 1928 & 121 \\
\hline & 71 & 22171 & 807 & 1109 & 209 & 437 & 364 & 20 & 21 & 1915 & 60 \\
\hline & 194 & 57075 & 8001 & 1836 & 42 & 1775 & 376 & - & 93 & 1683 & 58 \\
\hline & 123 & 45792 & 5547 & 683 & - & 351 & 51 & - & 54 & 736 & 29 \\
\hline & 179 & 84796 & 1570 & 3061 & 31 & 1194 & 436 & 17 & 78 & 2621 & 57 \\
\hline & 163 & 83542 & 1452 & 3082 & 32 & 1025 & 423 & 12 & 81 & 2230 & 51 \\
\hline & - & 4547 & 491 & - & - & 116 & 0 & - & - & 55 & - \\
\hline & 165 & 55534 & 1472 & 1518 & 43 & 497 & 82 & - & 30 & 826 & 18 \\
\hline & 77 & 14544 & 20573 & 789 & - & 454 & 55 & - & 13 & 220 & - \\
\hline & 60 & 19328 & 6194 & 225 & - & 120 & 58 & - & 14 & 761 & 37 \\
\hline \multirow[t]{14}{*}{ Qtz2-tg } & 34 & - & 5576 & - & - & - & - & - & - & - & - \\
\hline & 28 & 1435 & 4347 & 256 & - & - & - & 35 & 79 & 26 & - \\
\hline & - & 13807 & 1473 & - & - & 41 & 26 & - & 3 & 15 & - \\
\hline & 15 & - & 3709 & 136 & - & 0 & 13 & 17 & 11 & 22 & - \\
\hline & 12 & 2072 & 2215 & 480 & - & 25 & 12 & 29 & 17 & 298 & 75 \\
\hline & 79 & 12324 & 912 & 801 & 207 & 107 & 768 & 291 & 57 & 1252 & 60 \\
\hline & - & 566 & 6795 & - & 33 & 32 & 40 & 81 & 39 & 256 & - \\
\hline & - & 286 & 3846 & - & - & - & - & - & - & - & - \\
\hline & - & 3701 & 34084 & 0 & - & - & - & - & - & 90 & - \\
\hline & 105 & 10586 & 8055 & 2141 & 197 & 16 & 257 & 25 & 12 & 845 & 10 \\
\hline & 20 & 9524 & 4516 & 535 & 16 & 119 & - & 28 & 29 & 272 & - \\
\hline & 28 & 1927 & 110 & 467 & 33 & 1012 & 44 & - & 13 & 78 & 11 \\
\hline & 38 & 1703 & 983 & - & - & 14 & - & - & - & 67 & 579 \\
\hline & 226 & 14980 & 10130 & - & - & 202 & 180 & - & 64 & 257 & - \\
\hline \multirow[t]{4}{*}{ Qtz3-p } & 118 & 69072 & 5173 & 1462 & 21 & 1442 & 953 & 31 & 21 & 3068 & 87 \\
\hline & 126 & 68540 & 5236 & 1326 & 13 & 1563 & 1028 & 35 & 35 & 2958 & 80 \\
\hline & 120 & 70210 & 4852 & 1652 & 16 & 1402 & 1032 & 19 & 15 & 2500 & 70 \\
\hline & 145 & 67500 & 4956 & 1420 & 24 & 1453 & 856 & 29 & 42 & 2201 & 68 \\
\hline \multirow[t]{6}{*}{ Brt-p } & 136 & 87893 & 727 & 7834 & 921 & 6209 & 108 & 491 & 1266 & - & - \\
\hline & - & 13024 & 891 & 550 & 725 & 6239 & 174 & - & 1039 & - & - \\
\hline & 270 & 100224 & 1334 & 6569 & 765 & 1481 & 480 & - & 572 & - & - \\
\hline & 47 & 46184 & 1440 & 1255 & 579 & 4132 & - & - & 480 & - & - \\
\hline & - & 25417 & 1934 & 770 & 651 & 13028 & 140 & 97 & 448 & - & - \\
\hline & 126 & 72724 & 727 & 3885 & 1021 & 1173 & 19 & - & 683 & - & - \\
\hline
\end{tabular}




\begin{tabular}{|c|c|c|c|c|c|c|c|c|c|c|}
\hline 20 & 121753 & 432 & 1435 & 625 & 446 & 30 & 314 & 154 & - & - \\
\hline 26 & 67690 & 523 & 2525 & 308 & 438 & 1334 & - & 205 & - & - \\
\hline 128 & 104506 & 11103 & 2940 & 279 & 36104 & 243 & 54 & 239 & - & - \\
\hline 159 & 90848 & 910 & 5978 & 850 & - & - & 75 & 366 & - & - \\
\hline 17 & 37532 & 15 & 1068 & 875 & 42 & - & 34 & 390 & - & - \\
\hline- & 30265 & 57 & 1116 & 337 & 4317 & 199 & 316 & 198 & - & - \\
\hline - & 29730 & 15 & 1116 & 31 & 4317 & 199 & 297 & 141 & - & - \\
\hline 52 & 48389 & 332 & 2445 & 332 & 31 & - & 59 & 347 & - & $\begin{array}{c}- \\
(\mathrm{ppm})\end{array}$ \\
\hline
\end{tabular}

Appendix 1 : LA-ICP-MS data for four generations of fluids inclusions from the Sierra Almagrera 